\title{
MicroRNAs driving invasion and metastasis in ovarian cancer: Opportunities for translational medicine (Review)
}

\author{
CARLOS PALMA FLORES ${ }^{1 *}$, RAÚL GARCÍA-VÁZQUEZ ${ }^{2 *}$, DOLORES GALLARDO RINCÓN ${ }^{3}$, \\ ERIKA RUIZ-GARCÍA ${ }^{3}$, HORACIO ASTUDILLO DE LA VEGA ${ }^{4}$, LAURENCE A. MARCHAT ${ }^{2}$, \\ YARELY M. SALINAS VERA ${ }^{5}$ and CÉSAR LÓPEZ-CAMARILLO ${ }^{5}$ \\ ${ }^{1}$ Catedratico CONACYT and ${ }^{2}$ Molecular Biomedicine Program and Biotechnology Network, \\ Instituto Politécnico Nacional; ${ }^{3}$ Translational Medicine Laboratory, National Institute of Cancerology; \\ ${ }^{4}$ Laboratory of Translational Cancer Research and Cellular Therapy, National Medical Center 'Siglo XXI'; \\ ${ }^{5}$ Autonomous University of Mexico City, Genomics Sciences Program, Mexico City, Mexico
}

Received September 6, 2016; Accepted February 15, 2017

DOI: 10.3892/ijo.2017.3948

\begin{abstract}
Epithelial ovarian cancer is the fifth most frequent cause of cancer death in women. In spite of the advantages in early detection and treatment options, overall survival rates have improved only slightly in the last decades. Therefore, alternative therapeutic approaches need to overcome resistance and improve the patient survival and outcome. MicroRNAs are evolutionary conserved small non-coding RNAs that function as negative regulators of gene expression by inhibiting translation or inducing degradation of messenger RNAs. In cancer, microRNAs are aberrantly expressed thus representing potential prognostic biomarkers and novel therapeutic targets. The knowledge of novel and unexpected functions of microRNAs is rapidly evolving and the advance in the elucidation of potential clinical applications deserves attention. Recently, a specific set of microRNAs dubbed as metastamiRs have been shown to initiate invasion and metastasis in diverse types of cancer. We reviewed the current status of microRNAs in development and progression of ovarian cancer with a special emphasis on tumor cells invasion and metastasis. Also, we show an update of microRNA functions in oncogenic pathways and discuss
\end{abstract}

Correspondence to: Dr César López-Camarillo, Autonomous University of Mexico City, Genomics Sciences Program, San Lorenzo 290, Col. Del Valle, CP 03100 Mexico City, Mexico

E-mail: genomicas@yahoo.com.mx

${ }^{*}$ Contributed equally

Abbreviations: miRNAs, microRNAs; EMT, epithelial-mesenchymal transition; MET, mesenchymal-epithelial transition; OC, ovarian cancer; EOC, epithelial ovarian cancer; SOC, serous ovarian carcinoma

Key words: microRNAs, invasion, metastasis, epithelial-mesenchymal transition, ovarian cancer, translational medicine the current scenario for potential applications in clinical and translational research in ovarian cancer.

\section{Contents}

1. Introduction

2. MicroRNAs: novel regulators of gene expression

3. OncomiRs: microRNAs with key roles in cancer

4. Epithelial to mesenchymal transition: a key mechanism for invasion and metastasis

5. MicroRNAs are negative regulators of epithelial to mesenchymal transition in ovarian cancer

6. MetastamiRs: microRNAs driving invasion and metastasis in ovarian cancer

7. Possible exploitation of microRNAs in precision medicine

8. Conclusion

\section{Introduction}

Epithelial ovarian cancer (EOC) is a metastatic disease with the highest mortality rate of all gynecologic cancers (1). Serous, endometrioid, clear-cell, and mucinous ovarian cancers are the most frequent histotypes. These different ovarian cancer (OC) histotypes are characterized by altered genomic and epigenetic patterns which greatly impact oncogenic signalingpathways, behavior and clinical outcome. Hence, alternative therapeutic approaches are needed to improve the patient survival and outcome. Although no molecular predictors of clinical outcome are currently in use, several cellular factors have been studied as potential prognostic and predictive biomarkers (2). MicroRNAs (miRNAs) are small non-coding RNAs that function as negative regulators of gene expression (3). In cancer cells, miRNAs may function either as oncogenes or tumor-suppressors and may contribute to the heterogeneous biological behavior of ovarian tumors. One of the most deadly hallmarks of cancer cells is the ability to metastasize to other tissues and organs (4). Notably, metastasis can be promoted 
by specific sets of miRNAs which have the ability to target multiple genes related to cell migration and invasion $(5,6)$. In OC, metastasis is greatly promoted by the epithelial-tomesenchymal transition (EMT). A number of studies have focused on the discovery of key players in the EMT to identify potential targets for therapeutic intervention in precision medicine. Here, we reviewed the current status on the role of miRNAs in invasion and metastasis with a special emphasis in the potential applications in clinical and translational research in $\mathrm{OC}$.

\section{MicroRNAs: novel regulators of gene expression}

miRNAs are small non-coding RNAs of $\sim 22$ nucleotides in length which function as negative regulators of gene expression. These small RNAs function as guide molecules to base pairing with target genes resulting in translation repression or messenger RNA (mRNA) cleavage. miRNA biogenesis (Fig. 1) begins with their transcription by the RNA polymerase II which synthesize a primary miRNA (pri-miRNA) which contains both 5 -cap structure $\left({ }^{7} \mathrm{MGpppG}\right)$ as well as 3 '-end poly(A) tails (7). Pri-miRNAs are processed by the RNAse III-type protein Drosha which is associated to DGCR8 (DiGeorge syndrome critical region gene 8), KSRP and $\mathrm{p} 68$ proteins in a complex denoted as microprocessor. The cleavage of pri-miRNA by Drosha generates a 70-nucleotide precursor miRNA (pre-miRNA) that is exported into the cytoplasm by the Ran-GTP-dependent exportin 5 (8). The second step of pre-miRNA processing (dicing) is then performed by Dicer, an RNAse III enzyme which is associated to TRBP (TAR RNA-binding protein) or PACT, and Argonaute (AGO) proteins. This protein complex cleaves the pre-miRNA hairpin generating a double-stranded RNA of 22 nucleotides in length known as the miRNA:miRNA* duplex. Then the miRNA:miRNA* interacts with the associated RNA-induced silencing complex (RISC), which preferentially includes the miRNA guide strand and AGO. The mature miRNA bound to AGO hybridizes to complementary sequence in the 3 ' untranslated region (3'-UTR) of mRNA target. If miRNA binds to mRNA with non-perfect complementarity, it leads to translation repression. In contrast, if miRNA binds to target with a high complementarity, cleavage and degradation of mRNA is induced (9). The decay of mRNA is initiated by shortening of poly $\left(\mathrm{A}^{+}\right)$transcripts by the canonical deadenylation machinery in cytoplasmic foci denoted as P-bodies $(10,11)$.

\section{OncomiRs: microRNAs with key roles in cancer}

Aberrant expression of miRNAs is a common event during carcinogenesis as they regulate key transcripts involved in the initiation and progression of tumors, thus they have been denominated as oncomiRs (12). miRNAs with increased expression in tumors are frequently considered as oncogenes as they promote tumor development by inhibiting tumor suppressor genes. In contrast, miRNAs may function as tumor suppressors as they prevent tumor development by inhibiting oncogene expression or genes that controls cell differentiation and apoptosis (13). Aberrant expression of miRNAs is produced from genetic or epigenetic alterations represented by: i) deletions, ii) amplifications, iii) point mutations, iv)
DNA methylation, and v) chromatin modifications. Notably, several studies have identified miRNAs as useful biomarkers of diagnosis and prognosis in OC patients $(14,15)$.

\section{Epithelial to mesenchymal transition: a key mechanism for invasion and metastasis}

Epithelial to mesenchymal transition (EMT) is a morphogenesis program activated during embryonic development, tissues repair, fibrosis and cancer $(16,17)$. During tumor progression the EMT activation induces changes in epithelial cells that promote loss of basal apical polarity and cell-cell junctions. This allows that epithelial cells acquire plasticity, invasive capacity, stem cell-like characteristics and gain the ability to invade adjacent tissues and colonize distant organs (18) (Fig. 2). Cells that have undergone EMT also have the capacity to transform into epithelial cells in a reverse process known as mesenchymal to epithelial transition (MET). Both processes are important during embryo- and organogenesis, but in malignant transformation they represent a critical step to induce metastasis progression (19). Induction of EMT program is facilitated by growth factors produced from stromal cells that activate diverse signaling pathways including TGF- $\beta /$ BMP, WNT/ $\beta$-catenin, Hedgehog, Notch, Sonic and PI3K/AKT signaling pathways represent crucial mechanisms promoting EMT (20). Crosstalk between diverse signaling pathways promotes the expression of repressors of E-cadherin transcription such as: i) the Snail family of zinc-finger transcription factors Snail, Slug and Smuc; ii) the basic helix-loop-helix factors, Twist and E12/E47; iii) the two-handed zinc-finger factors of $\delta$-crystallin/E2 box factor 1 (dEF1) family proteins, dEF1/zinc-finger E-box-binding homeobox 1 (ZEB1), and iv) the Smad-interacting protein/ ZEB2 (21). In particular, E-cadherin plays an important role in the induction of EMT phenotype in cancer cells. E-cadherin is a membrane glycoprotein that mediates calcium-dependent cell-cell adhesion which is located at the adherens junctions predominantly associated with $\beta$-catenin. Under normal circumstances $\beta$-catenin binds E-cadherin providing a direct link between the E-cadherin cell-adhesion complex and the intracellular cytoskeleton (22). During EMT activation, $\beta$-catenin influences the transcriptional repressors Snail, Slug, and Twist to inhibit E-cadherin transcription (23).

Studies related to the characterization of EMT-induced signaling pathways have demonstrated that WNT signaling pathway is predominantly activated in EOC. Additional evidence reported that WNT signaling is negatively regulated by E-cadherin which in turn suppresses $\beta$-catenin expression and suppresses transcriptional activation of the EMT-related genes in OC (24). A number of studies have shown that Sonic Hedgehog signaling pathway also participate in the process of EMT. Upregulation of hedgehog glioma-associated oncogene 1 (shh-Gli1) promotes the activation of EMT event by crosstalk with PI3K-AKT pathways in OC (25). In this context, another mechanism has been described that sustains EMT by cooperative signaling. Rac-1, a specific guanine nucleotide exchange factor induce EMT in OC through simultaneous activation of mitogen-activated extracellular signal-regulated kinase 1/2 (MEK1/2) and Src signaling pathways (26). Another sophisticated regulatory network that regulates EMT 


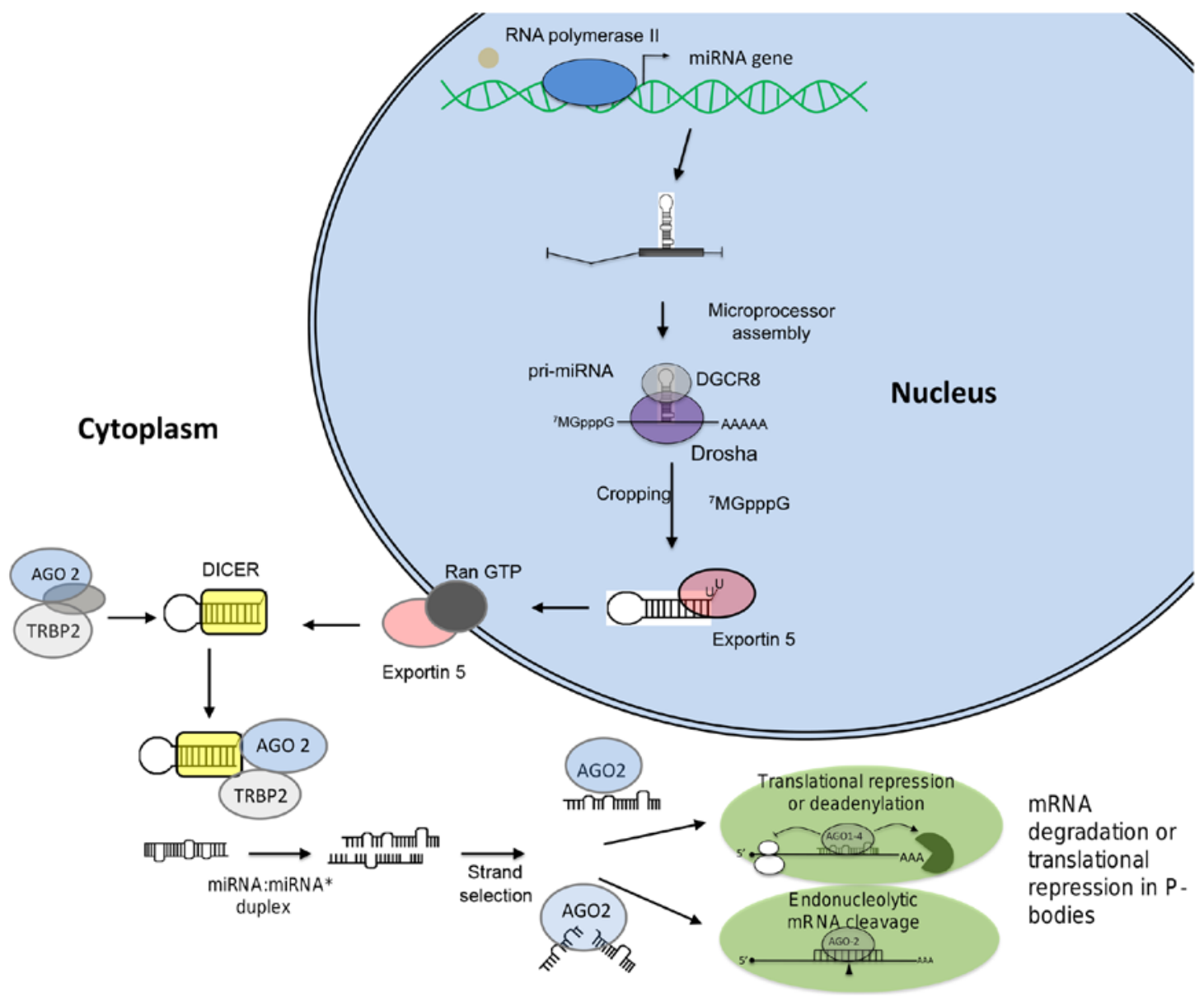

Figure 1. MicroRNA biogenesis. The main molecular steps required for miRNA process in the nuclei and cytoplasm.
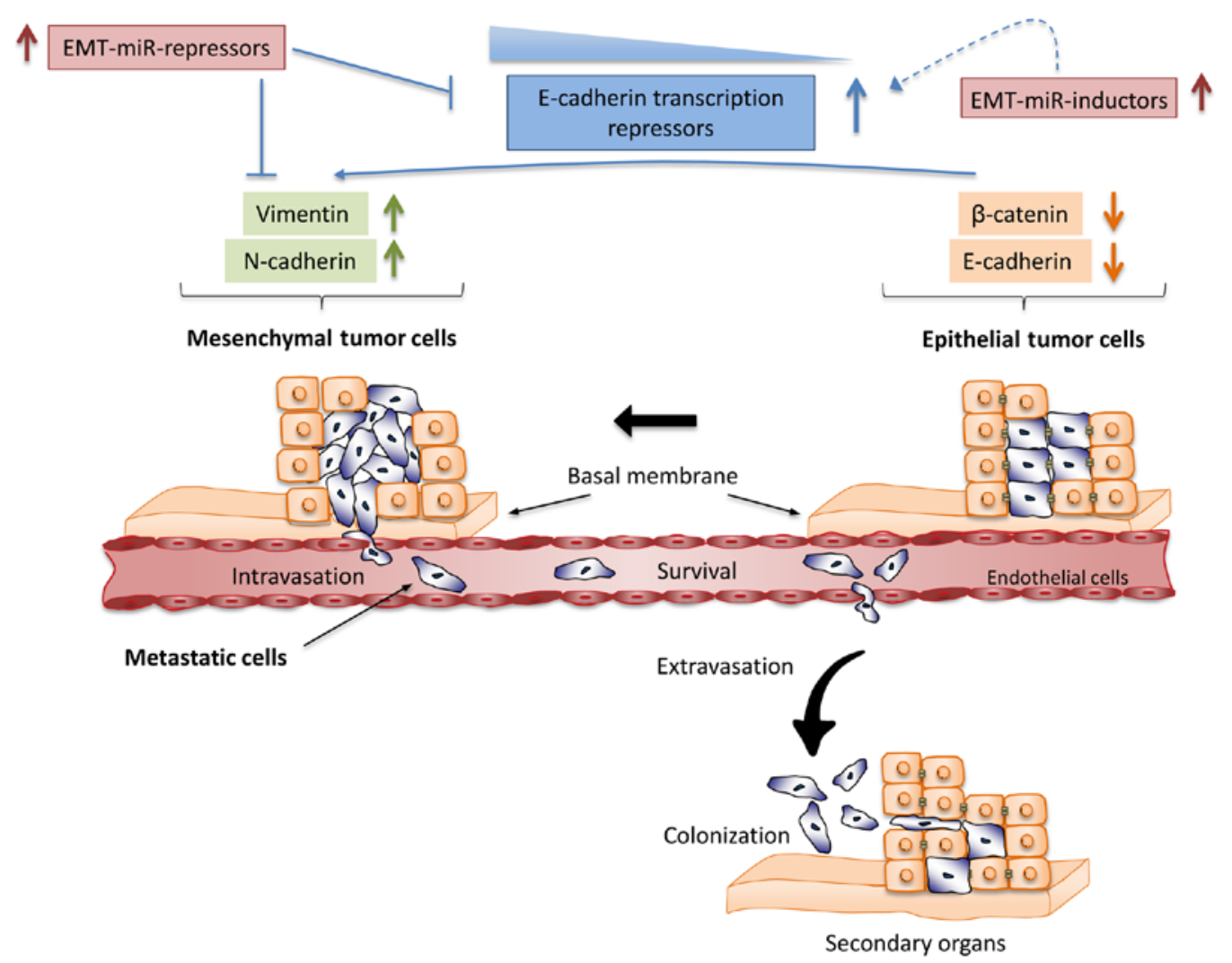

Figure 2. Schematic representation of epithelial-to-mesenchymal transition (EMT). The molecular mechanism by EMT converts epithelial cells into mesenchymal cell and shows the major molecular players that regulate the EMT process. 
is exerted by TGF- $\beta$ family. Recently, it was found that Smad4 mutations increased homodimerization of Smad4 with its receptor to promote nuclear localization leading to reduction of E-cadherin expression and increases of N-cadherin (27). In addition, crosstalk between TGF- $\beta$ and stem-cell promoting pathways facilitates the formation of Smad complex during EMT. Interestingly, the molecular basis of this cooperative mechanism indicates that many EMT signaling molecules interact with Smads to form complexes engaged in both repressing epithelial genes and activating mesenchymal genes (28). A number of studies have showed that microRNAs are important in the regulation of signaling proteins involved in the control of EMT. miRNAs are frequently engaged in feedback loops with signaling molecules, thus alterations in miRNAs expression may result in an imbalance of signals that promotes the activation of EMT program in cancer (29).

\section{MicroRNAs are negative regulators of epithelial to mesen- chymal transition in ovarian cancer}

MicroRNAs regulating ZEB1/ZEB2 transcription factors. Expression of genes responsible for EMT is mainly under control of ZEB1 (TCF8/ס-EF1) and ZEB2 (SIP1/ZFXH1B) transcription factors which repress E-cadherin whereas enhance vimentin and $\mathrm{N}$-cadherin. These changes in ZEB1 and ZEB2 expression constitute a signal for starting transition from epithelial to mesenchymal phenotype. Remarkably, it has been well demonstrated that miR-200 family members orchestrate the initiation of EMT by controlling the expression of ZEB1 and ZEB2 genes. The miR-200 family is expressed as two separate polycistronic pri-miRNAs: i) miR-200a, miR-200b, and miR-429 located on chromosome 1, and ii) miR-200c and miR-141 at chromosome 12 (30-34). Interestingly, miR-200 family members are differentially expressed in the bulk tumor. For instance, miR-200 members are expressed at low or negligible levels in normal ovarian surface cells and increased their expression in OC, whereas expression of ZEB1 and ZEB2 shows the opposite pattern. Ovarian surface cells acquire a more epithelial phenotype as they undergo transformation switching from a miR-200 family low and ZEB1/2 high state to a miR-200 family high and ZEB1/2 low phenotype (34). An early study which identified the relationship between miR-200 family and EMT process in EOC was carried out in the panel of 60 human cancer cell lines (NC160). One the most relevant findings of this study was the identification of miR-200 as a marker for E-cadherin-positive and vimentinnegative cancer cells in both the NC160 cells as well as in tumors from OC patients. This outstanding report showed that miR-200 targets the E-cadherin transcriptional repressors ZEB1 and ZEB2. Furthermore ectopic expression of miR-200 induced upregulation of E-cadherin in diverse cancer cell lines and reduction in their motility, while inhibition of miR-200 reduced E-cadherin expression and induced EMT associated to increased ZEB1 levels (33). On the other hand Chen et al performed a genome expression profile of two mesenchymallike OC cell lines with different metastatic potential and demonstrated that expression of miR-429, a member of the miR-200 family, resulted in the reversal of the mesenchymal phenotype through activation of the MET which was associated to changes in E-cadherin, ZEB1 and ZEB2 expression and migration and invasiveness (35). In addition, restoration of individual miR-200 members (miR-200a, miR-141, miR-200b and miR-200c) in HEY ovarian cancer cells also resulted in the acquisition of morphological epithelial characteristics, elevated expression of KRT8, KRT18 and KRT7 epithelial markers and reduced levels of ZEB1 and ZEB2. Remarkably, ectopic expression of miR-200 family members influenced the sensitivity of EOC to platinum-based drugs, which was associated to the inhibition of EMT that is known to reduce the sensitivity of chemotherapy (36). Besides these findings Chen et al reported that overexpression of miR-429 in a primary cell line (OCI-984) isolated from the ascites fluid an advanced stage OC patients also induced morphological, functional and molecular changes consistent with MET (35). Overexpression of miR-429 in OCI-984 cells also increased the sensitivity to cisplatin. Another study indicates that upregulation of miR-200c in ovarian cancer tissues was inversely associated with advanced clinical stage. miR-200c inhibited E-2 cells migration and invasion capacity through repression of ZEB2 (37). Moreover, miR-200c showed a potential function in stemness as it was downregulated in $\mathrm{CD} 44^{+} / \mathrm{CD} 117^{+}$ enriched stem-like cells derived from SKOV3 cells. Ectopic expression of miR-200c resulted in the inhibition of migration and invasion by downregulation of ZEB1 and vimentin, which in consequence upregulated E-cadherin in $\mathrm{CD} 44^{+} / \mathrm{CD} 117^{+}$ subpopulations. In addition miR-200c overexpression inhibited the EMT process and subsequently metastasis in $\mathrm{CD}_{4} 4^{+}$ $\mathrm{CD} 117^{+}$xenograft in nude mice (38).

On the other hand, ZEB1 was upregulated in high-grade serous ovarian carcinoma (SOC) specimens compared to normal fallopian tube tissue. In addition, miR-1236-3p suppressed migration and invasion abilities through targeting of 3'-UTR of ZEB1 in A2780 and SKOV3 cell lines (39). On the other hand $\mathrm{Wu}$ et al identified that ZEB2 is overexpressed in $\mathrm{CD} 133 / 1^{+}$ovarian cancer stem cells by downregulation of its repressor miR-200a. Conversely, ectopic expression of miR-200a in CD133/1+ ${ }^{+}$resulted in suppression of ZEB2 causing the increase of E-cadherin expression. Noteworthy these data show that loss of miR-200a expression may play a critical role in the repression of E-cadherin by ZEB2, thereby enhancing migration and invasion in CD133/1 $1^{+}$cells possibly through the acquisition of EMT phenotype (40).

Another microRNA that targets ZEB1 and control the EMT process is miR-150 which was downregulated in primary EOC tissues (41). Lower expression of miR-150 was associated with advanced clinical stage (III-IV) as well as with poor prognosis. Ectopic expression of miR-150 inhibits cell proliferation, invasion and metastasis (42). Targeted silencing of ZEB1 using shRNAs in SKOV3 cells resulted in enhanced expression of miR-200c and reduced EMT and metastasis. Downregulation of ZEB1 also decreased the growth of tumors in xenograft mouse model (43). Likewise, overexpression of miR-101 suppressed cell migration, invasion and EMT phenotypes by targeting ZEB1 and ZEB2 in SKOV3 cells. These phenotypes were associated to a significant increase in E-cadherin levels and decreases in mesenchymal markers (fibronectin, $\mathrm{N}$-cadherin and vimentin). In other related studies, Zhou et al reported that miR-153 also inhibits the EMT by targeting ZEB2 and Set7 (Set domain containing 7) genes (45). Set7 is a methyltransferase enzyme that trimethylates lysine 4 on 
histone 3 and epigenetic mark that has been found enriched in promoters of activated genes (44). In agreement with these findings and using an RNA mimic approach, it was demonstrated that miR-153 also promotes degradation of SET7/ ZEB2 transcripts which in turn leads to the inhibition of cell proliferation and EMT reducing the invasive potential of $\mathrm{OC}$ cells. In addition, miR-153 expression was downregulated in ovarian tumors and correlated with poor survival rates in EOC patients (45).

MicroRNAs regulating SNAI family of transcription factors. SNAI family of transcription factors consists of SNAI1 (often designated as SNAIL), SNAI2 (also known as SLUG) and SNAI3 (also known as SMUC), and they also suppress the expression of epithelial genes such as E-cadherin and activate the expression of mesenchymal genes including $\mathrm{N}$-cadherin and fibronectin (46). Yang et al performed an integrated genomic analysis and found that miR-506 inhibited cell migration and invasion and prevented TGF- $\beta$-induced EMT by targeting SNAI2 in SOC. In addition, miR-506 expression was associated with decreased SNAI2 and VIM, as well with increased E-cadherin levels. Interestingly, using a nanoparticle delivery system for miR-506 in orthotopic mouse models, a significant suppression of SNAI2/VIM and upregulation of E-cadherin expression was found (47). Functionally, miR-506 directly binds to the 3'-UTR of vimentin and N-cadherin genes in EOC (48). In addition using tissue microarrays including 204 EOC subtypes it was found that miR-506 expression was positively associated to E-cadherin and negatively correlated with vimentin and $\mathrm{N}$-cadherin. Noteworthy, all these findings confirms that loss of miR-506 expression resulted in mesenchymal phenotype in EOC. Thus, miR-506 is a potent regulator of both E-cadherin and vimentin/ $\mathrm{N}$-cadherin to suppress and control the EMT process and represents an innovative therapy against most aggressive ovarian cancers (49).

Another miRNA that regulates SNAI genes is the tumor suppressor miR-203. In human SOC tissues, miR-203 was found repressed whereas its target SNAI2 was upregulated. In addition, overexpression of miR-203 inhibited cell proliferation, migration and invasion in SKOV3 and OVCAR3 cells by suppression of EMT which was associated to E-cadherin upregulation and vimentin and SNAI2 downregulation. Outstandingly, through subcutaneously injection of miR-203expressing SKOV3 and OVCAR3 cells transduced with a lentiviral luciferase vector into immunodeficient NSG female mice, Zhao et al revealed that miR-203 inhibited EMT process and tumor growth in a xenograft mouse model (50).

Recently, Ye et al reported that during the induction of EMT by TGF- $\beta$, the miR-30b, miR-30c and miR-30d were suppressed in SKOV3 and $3 \mathrm{AO}$ cancer cells. In addition, restoration of miR-30d in TGF- $\beta$-induced EMT cancer cells induced the regression of EMT phenotypes including the morphological changes and the expression of E-cadherin and $\mathrm{N}$-cadherin markers. Also evidence that miR-30d directly targets the SNAIL gene was provided (51). Likewise, overexpression of miR-34a also inhibited the TGF- $\beta$-induced EMT process and leads to MET phenotype by downregulating SNAIL (52).

On the contrary, miR-520h regulates Twist an oncogenic transcription factor that plays a key role in EMT-mediated intravasation of tumor cells. Forced expression of miR-520h in SKOV3ip1 cells enhanced invasion and metastasis. In addition, E-cadherin was downregulated by miR-520h and associated to increased expression of Twist (53).

EMT-related genes are regulated by microRNAs. Several reports have identified diverse EMT-related genes as targets of microRNAs. For instance, miR-187 is an independent prognostic factor in OC and was associated with recurrence-free survival. Overexpression of miR-187 induced cell proliferation and inhibited cell migration. On the other hand, inhibition of miR-187 resulted in the upregulation of Dab2, repression of E-cadherin and increased vimentin levels which in turn promote the EMT phenotype. This means that miR-187 has a dual function; during the initial steps of tumorigenesis miR-187 may induce proliferation, but in the late stages it inhibits the EMT and tumor invasiveness by the suppression of Dab2. Another miRNA involved in the posttranscriptional regulation of EMT-related genes is miR-29b. This small RNA modulates the EMT by targeting the high mobility group A2 gene (HMGA2), a non-histone DNA binding protein that plays a very important role in fetal development and carcinogenesis. As an oncofetal gene it is overexpressed in tumors of both epithelial and mesenchymal tissues (54). Overexpression of HMGA2 in OSE cells induced spindle-like cell morphology, whereas its repression restored their epithelioid phenotype. In addition, HMGA2 overexpressing xenograft tumors resulted in the loss of E-cadherin and the increase of vimentin. Global expression profiling indicated that HMGA2-mediated tumorigenesis was associated with changes in the expression of miRNAs and target genes involved in EMT process. Among these, lumican (LUM) a tumor suppressor that inhibits EMT was found transcriptionally repressed by HMGA2 in OSE cell lines (55).

Furthermore, miR-373 was downregulated in cholangiocarcinoma and colon cancer and inversely correlated with clinical stage and histological grade in human EOC $(43,56)$. Ectopic expression of miR-373 in EOC cells suppressed cell invasion, metastasis and EMT process. Functional assays identified small GTPase Rab22a as a target of miR-373. Interestingly knockdown of Rab22a inhibits invasion, migration, and suppress N-cadherin in EOC cells. Metastasis was suppressed after restoration of miR-373 in xenograft ovarian carcinoma metastatic nude mice (57).

Recently, Hsiao et al reported that interferon $\alpha$-inducible protein 27 (IFI27) was upregulated in different types of cancer including OC. The IFI27 gene encodes a hydrophobic membrane protein that is highly induced by interferon- $\alpha / \beta$ to generate long-lasting immune response. By sending extracellular signals to activate other pro-apoptotic genes IFI27 functions as an apoptotic inducer (58). Notably, overexpression of IFI27 in OC cells induced EMT, cell migration, invasion, tumorigenicity, stemness, and drug resistance. Interestingly, in response to IFI27 the miR-502 expression was inhibited whereas its restoration inhibits IFI27-induced tumorigenicity, migration and drug resistance (59).

In another study conducted by Baskar et al it was found that the receptor tyrosine kinase orphan receptor 1 (ROR1) was overexpressed in chronic lymphocytic leukemia (60) and involved in the regulation of EMT mediated by miR-382. Using 
diverse experimental approaches it was shown that miR-382 expression was decreased in human OC tissues and cell lines. In addition, miR-382 inhibited cell proliferation, migration, invasion and EMT. These phenotypes were associated to a decrease of $\mathrm{N}$-cadherin and vimentin levels, as well as an increase of E-cadherin. In addition, using a luciferase assay it was revealed that miR-382 binds to the 3'-UTR of ROR1 gene (61). Other genes implicated in EMT that are bona fide targets of miR-138 were both the hypoxia-inducible factor-1 $\alpha$ $($ HIF-1 $\alpha)$ and the SRY-related high-mobility group box (SOX4). In agreement with these findings Yeh et al reported that the absence of HIF-1 $\alpha$ resulted in decreased SLUG levels. Likewise, knockdown of SOX4 resulted in the downregulation of epidermal growth factor receptor (EGFR) a gene involved in the activation of EMT. In highly invasive OC cell lines, miR-138 was found downregulated and its overexpression inhibited metastasis in ovarian cancer (62).

In another study miR-125, which is a tumor suppressor in different types of cancer also inhibited EMT process by targeting the AT-rich interactive domain 3B (ARID3B) gene (63). AIRD3B belongs to a family of AT-rich interactive domain (ARID) proteins that are involved in chromatin remodeling and gene expression regulation. ARID genes participate in development, tissue-specific gene expression and its aberrant expression is involved in tumorigenesis (64). Interestingly, miR-125 targets ARID3B and induced the conversion of highly invasive ovarian cancer cells from a mesenchymal to an epithelial morphology. Using multiple biochemical approaches, authors revealed that EGFR signaling leads to transcriptional repression of miR-125a through the ETS family transcription factor PEA3, which in consequence releases ARID3B to promote EMT (63).

MicroRNAs modulate EMT-associated signaling genes. Growing evidence indicates that activation of AKT, ERK1/2 and TGF- $\beta$ signaling pathways are essential for the induction of EMT genetic program. Since EMT-signaling pathways largely control metastasis, the investigations have been focused in the study of the interplay between microRNAs and novel genes modulating the EMT phenotype. Zhou et al reported that miR-7 plays a major role in the reversion of EMT by the inactivation of AKT and ERK1/2 pathways in EOC. Ectopic expression of miR-7 induced morphological changes from an elongated, spindle-shaped, mesenchymal phenotype to a rounded epithelial-like phenotype in highly metastatic HO-8910 and ES-2 cell lines. In addition, miR-7 expression was significantly downregulated in EOC cell lines and tissues, whereas EGFR expression correlated positively with metastasis in both EOC patients and cell lines. Moreover, miR-7 overexpression leads to the upregulation of CK-18 and B-catenin, and downregulation of vimentin by inactivation of EGFR/AKT and AKT/ER1/2 pathways. These changes were enough to inhibit cell migration, invasion and EMT events indicating that miR-7 is a tumor suppressor in EOC (65).

In SKOV3 and HO8920 spheroid cultures expressing EMT markers, Yuan et al found an increase of AKT1 levels. AKT1 belongs to the AKT/PKB subfamily of the serine/threonine kinases activated by growth factors through PI3K pathway and inhibited by phosphatase and tensin homolog deleted on chromosome 10 (PTEN) (66). Interestingly, transfection of
miR-20a downregulated the expression of PTEN resulting in the acquisition of cancer stem-like cells (CSCs) properties and induction of the EMT phenotype (67). Likewise, another report showed that miR-181a also induced the EMT process through the activation of TGF- $\beta$ pathway by repression of SMAD7 gene. Ectopic expression of miR-181a leads to increased cellular survival, migration, invasion, drug resistance and in vivo tumor burden and dissemination. In contrast, miR-181a inhibition resulted in a significant reversion of these phenotypes in high-grade SOC (68).

Another miRNA that controls EMT related pathways to suppress tumor cells invasion is miR-17-5p which was previously found increased in chemotherapy resistant colorectal tumors (69). In OC cells, miR-17-5p enhances cellular invasion, migration and EMT by targeting both PTEN and AKT (70). Introduction of miR-17-5p in OC cell lines repressed E-cadherin while increased N-cadherin, Snail and vimentin expression. In addition, forced expression of miR-17-5p decreased PTEN while increased p-AKT in OVCAR3 and SKOV3 cell lines (70).

Other studies have focused on the role of miRNAs and metastasis in cancer stem cells. For instance, downregulation of miR-155 in OC stem-like cells $\left(\mathrm{CD} 44^{+} / \mathrm{CD} 117^{+}\right)$resulted in downregulation of claudin-1 (CLD-1). In vitro and in vivo assays showed that restoration of miR-155 expression inhibits the migration and invasion in $\mathrm{CD} 44^{+} / \mathrm{CD} 117^{+}$subpopulations by suppression of CLD-1. In addition, transfection of miR-155 did not induce changes in MMP-2 and MMP-9 expression, but a significantly increase of E-cadherin and $\beta$-catenin was found in agreement with acquisition of epithelial phenotype (71). All these reports evidence the alterations in the regulation network of miRNAs and EMT-related genes which are summarized in Fig. 3.

\section{MetastamiRs: microRNAs driving invasion and metastasis in ovarian cancer}

During the last decade a number of aberrantly expressed miRNAs have been identified as key promoters of cell migration and invasion in OC (Fig. 3). In early studies, Iorio et al reported a miRNA expression profile in different histotypes and clinical stages of EOC. They reported the downregulation of miR-144 and miR-216 in lymphovascular invasion; and miR137, miR-101, miR-215 and miR-211 in OC with tubal involvement. In contrast, upregulation of miR-101, miR-182*, miR-22 and miR-133a was found in OC with ovarian surface involvement, miR-302c in pelvic peritoneum involvement, and miR-133a-2, miR-143, miR-145, miR-1, miR-147 and miR-126 in OC with uterus involvement. Subsequent functional studies gave insights into the role of some deregulated miRNAs in invasion and metastasis in OC (72).

MicroRNAs functioning as tumor suppressors. Degradation of the extracellular matrix is a complex process that stimulates cell migration, invasion and metastasis in many types of cancer. In endometrial carcinoma histotype, $28 \%$ of cases exhibit metastasis at diagnosis. Some miRNAs functioning as a tumor suppressor have been identified as deregulated in this particular OC. For instance, Habata et al found that BCL2associated athanogene (BAG3) inhibited the expression of 
A

miR-144, miR-216, miR-137, miR-101, miR-215, miR-211, miR-520d-3p, let-7, let-7a, let-7e, let-7f, miR-886-5p, miR-183, miR-31, miR-138, miR-212, miR-16, miR-335, miR-490-3p, miR-93-5p, miR-34 family, miR-708, miR-92a, miR-9, miR-155, miR 382, miR-1236-3p, miR-150, miR-153, miR-200 family, miR-497, miR-206, miR-548c, miR-29b, miR 204, miR-338-3p, miR-124, miR-148a, miR-125a, miR-125b, miR-373, miR-613, miR-761, miR-182*, miR-133a, miR-302c, miR-133a-2, miR-143, miR-1, miR-147c, miR-126, miR-27b, miR-520h, miR-205, miR-10b, miR-17, miR-17-5p, miR-21, miR-182, miR-7, miR-25, miR-181b, miR-27, miR-191, miR 20a, miR-197, miR-22, miR-145, miR-429, miR 200a, miR-146a, miR-199a, miR-210, miR-193b, miR-630, miR-181c, miR-21-3p, miR-38.

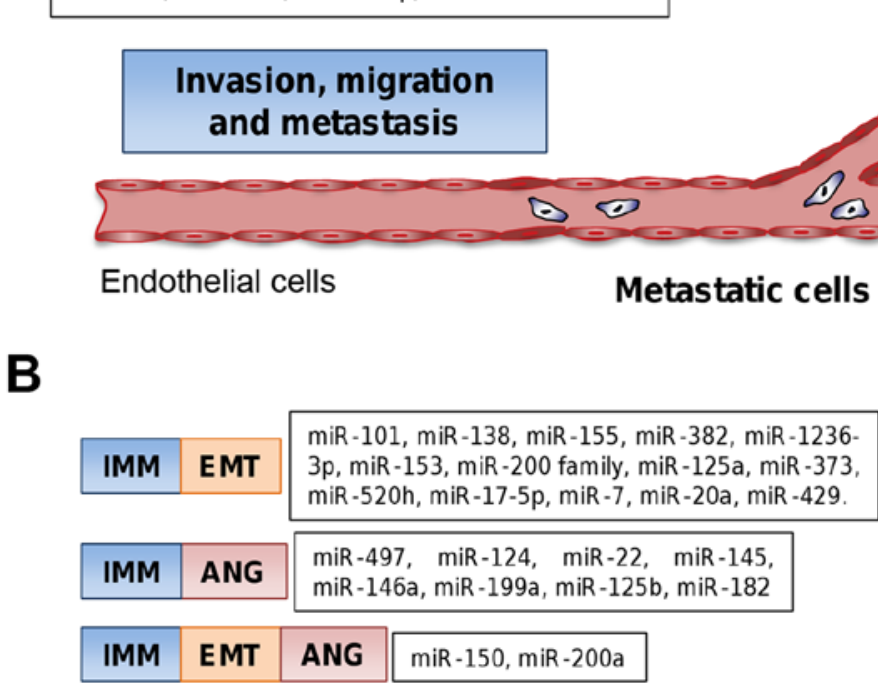

\section{Mesenchymal tumor cells}

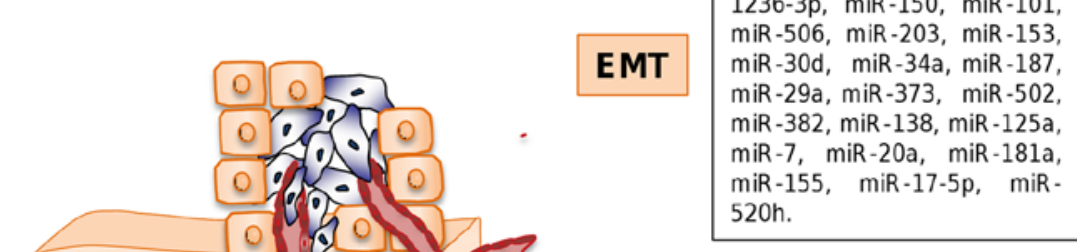

Figure 3. MicroRNAs involved in ovarian cancer. (A) The microRNAs involved in the regulation of epithelial-to-mesenchymal transition (EMT), angiogenesis (ANG), invasion, migration and metastasis process (IMM). (B) The miRNAs involved in common cellular processes.

miR-29b in endometroid adenocarcinoma cells. Congruently, knockdown of BAG3 led to increased levels of miR-29b in Ishikawa and HEC108 cells. Restoration of miR-29b using RNA-mimics decreased migration and invasion presumably by inhibition of metallopeptidase 2 (MMP2) gene (73). On the other hand, Sun et al demonstrated that Twist regulates miR-548c expression. Ectopic expression of miR-548c inhibited cell proliferation, migration and invasion, while Twist restoration abrogates the suppressive effect of $\mathrm{miR}-548 \mathrm{c}$ in cell migration and invasion in RL95-2 and HEC-1 ovarian cells (74).

MicroRNAs functioning as oncogenes. A number of miRNAs activates the cancer hallmarks thus functionioning as oncogenes in OC. For instance, miR-205 is frequently overexpressed in endometrial carcinoma (EC) and it is related to metastasis. Experimental inhibition of miR-205 decreased cell proliferation, migration and invasion in Ishikawa cells by targeting the estrogen-related receptor- $\gamma$ (ESRRG) tumor suppressor gene (75). Another study showed that upregulation of miR-27 was associated with myometrial invasion in ECC. In addition, FOXO1 transcription factor was found downregulated in invasive ECC indicating that miR-27-FOXO1 axis inhibits invasiveness and apoptosis in tumors (76). Moreover,
Dong et al showed that miR-191 had a negative correlation with tissue inhibitor of metalloprotease 3 (TIMP3) expression in tissues and serum of patients with endometriosis-associated ovarian cancer (EAOC). Notably, miR-191 was overexpressed in EAOC and its knockdown significantly inhibited cell invasion by upregulation of TIMP3 in CRL-11731 cells. These data indicate that miR-191-TIMP3 axis is involved in the malignant transformation of endometriosis to EAOC (77).

\section{Hormonal receptors and microRNAs in cell invasion}

MicroRNAs acting as tumor suppressors. Hormonal receptors interplaying with miRNAs regulate invasion and metastasis of tumor cells. Expression of estrogen receptor- $\alpha$ (ER- $\alpha)$ and downregulation of miR-22 were associated with cell invasion in ER- $\alpha$ positive EC subtype. In addition, it was demonstrated that ER- $\alpha$ is a direct target of miR-22. Likewise, ectopic expression of miR-22 in RL95-2 and Ishikawa cells abrogates the invasion induced by $17 \beta-\mathrm{E} 2$ (E2) through downregulation of cyclin D1 and MMP2 and MMP9. Thus, E2-ER- $\alpha$ axis represents a potential candidate for endocrine therapy in OC (78). On the contrary, it was reported that miR-206 was significantly downregulated in ER- $\alpha$ positive EC and that its suppression was modulated by E2. Ectopic expression of miR-206 decreased ER- $\alpha$ positive-dependent proliferation and 
invasion in EC cells. Thus, miR-206 also could be a potential tool for endocrine therapy in ER- $\alpha$ positive EC patient $(79,80)$.

\section{MicroRNAs associated with highly aggressive phenotypes of} ovarian cancer

MicroRNAs acting as tumor suppressors. Recent findings from diverse research groups pointed out that altered miRNAs expression was associated with aggressive phenotypes of OC. Downregulation of tumor suppressors let-7a, let-7e, let-7f, miR-886-5p and miR-22 have been associated with aggressive behavior of tumors and represents potential markers of invasion and metastasis in EOC (81). Particularly, miR-22 has a critical role on malignancy and metastasis in all subtypes of OC. Li et al showed that overexpression of Tiam1, a guanine nucleotide exchange factor, correlated with metastatic phenotypes of OC. Authors showed that miR-22 is downregulated in ovarian cancer and negatively associated with metastasis in SOC cells. Intriguingly, the manipulation of miR-22 expression had inhibitory effects on cell migration and invasion, but not in cell viability and apoptosis (82). In agreement with these findings, miR-22, miR-183 and miR-31 suppressed cell migration and invasion of SOC cells, at least in part, by downregulation of Tiam1 (83).

In other studies, Wen et al reported that miR-338-3p expression was repressed in EOC tissues and correlated with malignancy. Ectopic expression of miR-338-3p triggers apoptosis and activation of caspases 3, 8 and 9. In addition, miR-338-3p inhibits MMP-2 and MMP-9 resulting in reduced cell migration and invasion abilities. Overexpression of miR-338-3p induced the downregulation of Runx2, which in turn abolish the phosphorylation of PI3K (Tyr458) and AKT (Ser473 and Thr308). Cell migration and invasion were inhibited by PI3K/AKT signaling pathways (84). In other studies, it was found that miR-708 was downregulated in SKOV-I6iv cells and associated with advanced-stage ovarian cancer (III/IV stages). In vitro assays showed that the restoration of miR-708 attenuated the cell invasion and metastasis in orthotopic xenograft mouse model through suppression of Rap1B. Loss of Rap1B resulted in increased focal adhesions (85).

Furthermore, miR-124 was downregulated in highly metastatic OC cells. Ectopic expression of miR-124 suppressed the expression of sphingosine kinase 1 (SphK1), a protein associated with tumor cell invasion and metastasis. Knockdown of SphK1 using miR-124 inhibited the cell motility in SKOV3 and HO8910 cells (86). Thereafter, Wen et al found that sphingosine-1-phosphate receptor 1 (S1PR1) was also suppressed by miR-148a. Overexpression of miR-148a resulted in the inhibition of cell migration and invasion in SKOV3 cells (87).

Moreover, two reports showed that low levels of miR-138 were associated with invasion and metastasis without affecting growth of tumors $(62,88)$. In the first study, ectopic expression of miR-138 reduced the cell migration and metastasis ability by targeting SOX4 and hypoxia-inducible factor-1 $\alpha$ (HIF-1 $\alpha$ ). Knockdown of SOX4 and HIF-1 $\alpha$ in SKOV-I6 cells abolished the invasion through the signaling downstream of EGFR and Slug. Thus low levels of miR-138 and high expression of SOX4 could represent a prognostic marker and a target for intervention of OC metastasis (62). In the second report, suppression of the expression of miR-138 was found in highly malignant phenotypes of OC tissues. Notably, miR-138 inhibits cell invasion and metastasis by targeting LIM kinase 1 (Limk1) via Limk1/cofilin/p-cofilin axis and modulation of PCNA and Bcl-2 (88).

Another report indicates that EPH receptor A2/B2 (EphA2/B2) is implicated in malignancy of OC. Knockdown of EphA2 expression or ectopic expression of miR-520d-3p in vitro abolished the migration and invasion of cancer cells and decreased the tumor growth in vivo (14). It has been indicated that motility of the ovarian cancer cells can be promoted by ubiquitin ligases. Wang et al reported that higher levels of pro-metastatic factor SMAD specific E3 ubiquitin protein ligase 1 (SMURF1) were associated with shorter overall survival, whereas downregulation of miR-497 correlated with aggressive phenotypes of OC. Exogenous expression of miR-497 abolished the cell migration and invasion through direct inhibition of SMURF1 activity. In agreement with these data, restoration of miR-497 decreased invasiveness and was associated to better survival of patients (89). On the other hand, Lee et al elucidated a link between translation machinery and miRNAs. Ectopic expression of miR-125a and miR-125b decreasd cell invasion and migration by targeting the eukaryotic translation initiation factor $4 \mathrm{E}$ binding protein 1 (EIF4EBP1) gene (90).

MicroRNAs acting as oncogenes. Some miRNAs could have a dual role as tumor suppressor or oncogene in cancer cells. For instance, miR-7 expression was identified downregulated in EOC tumors (65). However, Meng et al identified that miR-7 and miR-429 were overexpressed in serum of EOC patients. In vitro miR-429 inhibited the cell migration and invasion. Authors proposed that miR-429 could have a dual role acting as tumor suppressor and oncogene because miR-429 levels were high in patients with primary EOC while they diminished in patients with distant migration and metastasis (91).

MicroRNAs regulating intercellular junctions and cytoskeletal dynamics in ovarian cancer

MicroRNAs functioning as tumor suppressors. Actin cytoskeleton regulates the formation of F-actin-rich membrane protrusions leading to motility and cellular adhesion. Cao et al found that overexpression of miR-335 inhibited cell migration and invasion through the depolymerization of F-actin in OC cells. Moreover, miR-335 suppressed B-cell CLL/lymphoma w (BCL-w) and its effector MMP2. Lack of miR-335 expression resulted in the accumulation of BCL-w and acquisition of a more invasive phenotype (92).

Using high-resolution miRNAs comparative genomic hybridization (CGH), Imam et al identified a genomic loss of miR-204 in $44.63 \%$ of OC (93). Tumor suppressor miR-204 is frequently downregulated in diverse types of cancer $(94,95)$. Authors demonstrated that miR-204 target the brain-derived neurotrophic factor (BDNF) gene which bind and activate the tropomyosin-related kinase B (TrkB). The BDNF/TrkB complex enhanced invasiveness and angiogenesis through subsequent activation of the small GTPase Racl and actin reorganization through the AKT/mTOR signaling pathway. Overexpression of miR-204 reduced colony-forming capacity and migratory and invasive capabilities of SKOV3 and HEK-293 cells lines. Interestingly, injection of the miR-204 in the breast cancer lung metastasis model led to suppression of 
lung metastases (93). Likewise, expression of miR-9 inhibited the focal adhesion protein talin 1 (TLN1). Downregulation of TLN1 was associated with decreased cell migration and invasion in serous ovarian cancer through downregulation of FAK/AKT pathway (96). Besides, Ohyagi-Hara found that overexpression of the integrin subunit $\alpha 5$ (ITGA5) correlated with peritoneal dissemination in OC. Restoration of miR-92a suppressed cell adhesion mediated by ITGA5, as well as cell invasion and proliferation in OC cells. ITGA5 was confirmed as a target of miR-92a and its inhibition resulted in the peritoneal dissemination of cancer cells (97). Finally, Doberstein et al found that overexpression of miR-21-3p modulated the expression of L1 cell adhesion molecule (L1CAM), which is a protein associated with metastasis in OVMz cells (98).

MicroRNAs associated with p53 activity in ovarian cancer MicroRNAs functioning as a tumor suppressor. Loss or dysfunction of tumor suppressor p53 greatly contributes to tumorigenesis in more than half of all types of cancers. Chen et al demonstrated that restoration of miR-490-3p in EOC metastatic cells resulted in increased levels of $\mathrm{p} 53$. Overexpression of miR-490-3p in vitro suppressed cell migration and invasion as well as cell proliferation, and in vivo decreased the tumor development. Notably, miR-490-3p targets cyclin-dependent kinase 1 (CDK1) which participates together with Bcl-xL, CCND1, and MMP-2/9 enhancing tumorigenesis in OC. By decreasing CDK1 expression through miR-490-3p and stimulating the expression of $\mathrm{p} 53$, miR-490-3p potentially may suppress the tumorigenesis and metastasis progression in EOC (99). In addition, Chen et al suggested that the expression of tumor suppressor miR-93-5p activates p53 while represses poly (ADP-ribose) polymerase (PARP) expression through inhibition of RAS homolog gene family member C (RhoC), P70S6 kinase, Bcl-xL and MMP-9. Functional studies confirmed that $\mathrm{RhoC}$ is a target of miR-93-5p. In addition, overexpression of miR-93-5p in vitro inhibited invasion and proliferation of cancer cells, and the in vivo tumor development (100). Moreover, Liu et al showed that the expression of p53 and p21 was decreased because downregulation of serine/threonine kinase 11 (LKB1), which was inhibited by miR-17 in CD44-/CD117 cancer cells. Expression of miR-17 modulated the migration and invasion in CD44\% CD117 cells through suppression of the LKB1-p53-p21/WAF1 pathway. The suppression of LKB1-p53-p21/WAF1 by miR-17 resulted in increased invasiveness of $\mathrm{CD} 44^{+} / \mathrm{CD} 117^{+}$cells (101).

The miR-34 family plays a key role in cell proliferation and invasion of EOC cells. Corney et al showed that miR-34 family is downregulated in OC with or without p53-mutated. They found that $\mathrm{miR}-34 \mathrm{~b} / \mathrm{c}$ levels are lower in advanced OC and the expression of miR-34a was negatively associated with the expression of the proto-oncogene receptor tyrosine kinase (MET). Ectopic expression of miR-34 family members into SKOV-3 cells decreased MET significantly and resulted in the inhibition of cell motility and invasion (102). A further study highlighted that miR-34 family is activated in the presence of functional p53. MET can be suppressed through miR-34 in a p53-dependent way $(103,104)$. In addition, Li et al reported that miR-34a inhibits cell invasion and proliferation by downregulating the AXL receptor tyrosine kinase (105).
Downregulation of miR-145 has been reported in tumor tissues, serum and OC cancer cell lines (106). Additional reports showed that $\mathrm{p} 53$ regulated the expression of miR-145 and p53 is dysfunctional in high-grade SOC $(107,108)$. Functional studies using RNA mimics revealed a suppressive role of miR-145 in cell viability, invasion, cell growth, cell proliferation and colony formation in OC cells. Moreover, cell colony formation and invasion were mediated by P70S6K1 and MUC1, respectively. Both genes were confirmed as true targets of miR-145 (106). Another study found that miR-145 also targets the motif containing 2 (TRIM2) gene. Inhibition of TRIM2-BIM pathway through antagomiR-145 in EOC resulted in decreased tumorigenicity (109). Moreover, Dong et al found that metadherin (MTDH) oncogene, which was overexpressed in SOC, is a target of miR-145. Inhibition of MTDH by miR-145 abolished the cell migration and invasion, and reduced tumor growth and metastasis (108). In other studies, Kim et al found an inverse expression between miR-145 and HMGA2 during ovarian cancer metastasis. In vitro, ectopic expression of miR-145 inhibited cell growth and migration. Finally, low levels of miR-145 and high expression of HMGA2 represent biomarkers of poor prognosis in ovarian cancer (110).

\section{Long non-coding RNAs regulate tumor suppressor let-7}

MicroRNAs acting as tumor suppressors. Long non-coding RNA can act as molecular sponge to suppress miRNAs in cancer cells. Yan et al identified that H19 long non-coding RNA suppressed the activity of let-7 in A2780 cells. Silencing of $\mathrm{H} 19$ decreased the cell migration and invasion processes by restoration of let-7 activity and inhibition of its targets genes including HMGA2, c-Myc and Igf2bp3. A positive correlation between the expression of H19 and Hmga2, c-Myc and Igf $2 \mathrm{bp} 3$ was also identified. Suppression of let-7 activity by H19 may explain why the overexpression of let-7 is associated with poor prognosis in ovarian cancer (111). On the other hand, Gao et al reported that HOST2 long non-coding RNA is overexpressed in EOC resulting in the inhibition of let-7b. Targeting of HOST2 leads to decreased cell migration and invasion in OVCAR3 cells (112).

\section{MicroRNAs regulating the microRNA biogenesis machinery} MicroRNAs acting as oncogenes. Biogenesis of miRNAs is epigenetically and transcriptionally controlled resulting in tissue specific miRNA expression patterns. However, alterations in the basic components of the miRNAs biogenesis machinery can promote carcinogenesis. Guo et al identified that knockdown of DiGeorge critical region 8 (DGCR8), a component of the microprocessor complex, reduced cell migration and invasion through attenuation of ERK1/2, PI3-K and AKT pathways, as well as sensitizes cells to apoptosis induced by the chemotherapeutic drug cisplatin. In addition, DGCR8 knockdown resulted in dysregulated miRNA gene expression. miR-27b was identified as the most highly downregulated miRNA in DGCR8 knockdown cells and promoted cell proliferation in OC cancer cells (113). On the contrary, Rupaimoole et al showed that low levels of Dicer during hypoxia conditions were due to upregulation of miR-630 in ovarian cancer. In addition, using luciferase reporter assays Dicer was confirmed as target of miR-630. 
Table I. MicroRNAs targeting EMT with potential therapeutic applications into translational medicine.

\begin{tabular}{|c|c|c|c|c|c|c|c|}
\hline \multirow[b]{2}{*}{ miRNA } & \multicolumn{7}{|c|}{ Epithelial mesenchymal transition } \\
\hline & $\begin{array}{c}\text { Expression } \\
\text { in ovarian } \\
\text { cancer }\end{array}$ & $\begin{array}{l}\text { In vitro } \\
\text { effect }\end{array}$ & $\begin{array}{l}\text { Target } \\
\text { genes }\end{array}$ & $\begin{array}{l}\text { Downstream } \\
\text { genes }\end{array}$ & $\begin{array}{l}\text { In vivo } \\
\text { effect }\end{array}$ & $\begin{array}{l}\text { Potential } \\
\text { therapeutic } \\
\text { candidate }\end{array}$ & $\begin{array}{l}\text { Authors/ } \\
\text { Refs. }\end{array}$ \\
\hline $\operatorname{miR}-200 c$ & $\begin{array}{l}\text { Suppressed in } \mathrm{CD} 44^{+} / \\
\mathrm{CD} 177^{+} \text {cells }\end{array}$ & $\begin{array}{l}\text { Inhibition of cell } \\
\text { migration/invasion } \\
\text { and EMT }\end{array}$ & ZEB1 & $\begin{array}{l}\uparrow \text { E-cadherin } \\
\downarrow \text { Vimentin }\end{array}$ & $\begin{array}{l}\text { Inhibits xenograft } \\
\text { growth and lung } \\
\text { metastasis by EMT }\end{array}$ & Yes & $\begin{array}{l}\text { Chen } \\
\text { et al (38) }\end{array}$ \\
\hline miR-506 & $\begin{array}{l}\text { Suppressed in SOC } \\
\text { specimens }\end{array}$ & $\begin{array}{l}\text { Inhibition of cell } \\
\text { proliferation } \\
\text { migration/invasion } \\
\text { and TGFB1- } \\
\text { induced EMT }\end{array}$ & $\begin{array}{l}\text { SNAI2 } \\
\text { CDH2 } \\
\text { VIM }\end{array}$ & $\begin{array}{l}\uparrow \text { E-cadherin } \\
\downarrow \text { N-cadherin } \\
\downarrow \text { Vimentin }\end{array}$ & $\begin{array}{l}\text { Inhibits tumor } \\
\text { growth, EMT, } \\
\text { invasion and } \\
\text { metastasis in } \\
\text { SKOV3/HeyA8 } \\
\text { orthotopic model }\end{array}$ & Yes & $\begin{array}{l}\text { Yang } \\
\text { et al (47) } \\
\text { Sun } \\
\text { et al (48) } \\
\text { Sun } \\
\text { et al (49) }\end{array}$ \\
\hline miR-203 & $\begin{array}{l}\text { Suppressed in SOC } \\
\text { specimens }\end{array}$ & $\begin{array}{l}\text { Inhibition of cell } \\
\text { proliferation, } \\
\text { migration/invasion } \\
\text { and TGFB1- } \\
\text { induced EMT }\end{array}$ & SNAI2 & $\begin{array}{l}\uparrow \text { E-cadherin } \\
\downarrow \text { Vimentin }\end{array}$ & $\begin{array}{l}\text { Inhibits SKOV3/ } \\
\text { OVCAR3 xenograft } \\
\text { xenograft growth } \\
\text { and EMT }\end{array}$ & Yes & $\begin{array}{l}\text { Zhao } \\
\text { et al (50) }\end{array}$ \\
\hline miR-373 & $\begin{array}{l}\text { Suppressed in EOC } \\
\text { specimens }\end{array}$ & $\begin{array}{l}\text { Inhibition of cell } \\
\text { migration/invasion } \\
\text { and EMT }\end{array}$ & Rab22a & $\begin{array}{l}\uparrow \text { E-cadherin } \\
\downarrow \text { N-cadherin }\end{array}$ & $\begin{array}{l}\text { Inhibits metastasis } \\
\text { in xenograft } \\
\text { metastatic models }\end{array}$ & Yes & $\begin{array}{l}\text { Zhang } \\
\text { et al ( } 57)\end{array}$ \\
\hline $\operatorname{miR}-138$ & $\begin{array}{l}\text { Suppressed in OC } \\
\text { specimens }\end{array}$ & $\begin{array}{l}\text { Inhibition of cell } \\
\text { migration/invasion } \\
\text { and EMT }\end{array}$ & HIF-1 & $\begin{array}{l}\text { EGFR } \\
\text { SLUG }\end{array}$ & $\begin{array}{l}\text { Inhibits metastasis } \\
\text { in GFP/SKOV-16iv } \\
\text { orthotopic model }\end{array}$ & Yes & $\begin{array}{l}\text { Yeh } \\
\text { et al (62) }\end{array}$ \\
\hline $\operatorname{miR}-181 \mathrm{a}$ & $\begin{array}{l}\text { Overexpressed in } \\
\text { EOC specimens }\end{array}$ & $\begin{array}{l}\text { Increase of cell } \\
\text { migration/invasion } \\
\text { and EMT }\end{array}$ & SMAD7 & $\begin{array}{l}\downarrow \text { E-cadherin } \\
\downarrow \text { Keratin } 8 \\
\uparrow \text { N-cadherin } \\
\uparrow \text { Fibronectin } \\
\uparrow \text { Co13A1 }\end{array}$ & $\begin{array}{l}\text { Increases EMT and } \\
\text { metastasis in intra- } \\
\text { peritoneal and intra- } \\
\text { bursal orthotopic } \\
\text { xenograft mouse } \\
\text { models of OC }\end{array}$ & Yes & $\begin{array}{l}\text { Parik } \\
\text { et al (68) }\end{array}$ \\
\hline $\operatorname{miR}-155$ & Suppressed in OC & $\begin{array}{l}\text { Inhibition of cel } \\
\text { proliferation, } \\
\text { migration and } \\
\text { invasion }\end{array}$ & CLDN1 & $\begin{array}{l}\uparrow \text { E-cadherin } \\
\uparrow \text { B-catenin } \\
\downarrow \text { MMP-2 } \\
\downarrow \text { MMP-9 }\end{array}$ & $\begin{array}{l}\text { Inhibits tumor } \\
\text { growth and reduces } \\
\text { proliferation of } \\
\text { OCICs xenograft } \\
\text { mouse model }\end{array}$ & Yes & $\begin{array}{l}\text { Qin } \\
\text { et al }(71)\end{array}$ \\
\hline
\end{tabular}

OC, ovarian cancer; EOC, epithelial ovarian cancer.

The delivery of miR-630 in nano-liposomes in an orthotopic mouse model of OC resulted in increased tumor growth and metastasis (114).

\section{MicroRNAs regulating cellular growth factors}

MicroRNAs as tumor suppressors. Growth factors are key promoters of tumor cell motility, invasiveness and metastasis. For instance, Tang et al demonstrated in vitro that miR-16 suppressed invasion through downregulation of vascular endothelial growth factor (VEGF), MMP-2 and BCL-2 genes (115). Another study showed that the heparin binding epidermal growth factor (HBEGF) was repressed by miR-212. This miRNA was found downregulated in tumor tissues and patient's serum with EOC. Overexpression of miR-212 in SKOV3 cells suppressed cell proliferation, migration and invasion (116). Recently, Li et al identified a correlation between downregulation of miR-217 with metastasis in EOC. Ectopic expression of miR-217 in EOC cells decreased cell prolif- 
Table II. MicroRNAs targeting invasion and metastasis with potential therapeutic applications in translational medicine.

\begin{tabular}{|c|c|c|c|c|c|c|c|c|}
\hline \multirow[b]{2}{*}{ miRNA } & \multicolumn{8}{|c|}{ Migration, invasion and metastasis } \\
\hline & $\begin{array}{c}\text { Expression } \\
\text { in ovarian } \\
\text { cancer }\end{array}$ & $\begin{array}{l}\text { In vitro } \\
\text { effect }\end{array}$ & $\begin{array}{l}\text { Cancer } \\
\text { cells }\end{array}$ & Target & $\begin{array}{l}\text { Downstream } \\
\text { genes }\end{array}$ & $\begin{array}{l}\text { In vivo } \\
\text { effect }\end{array}$ & $\begin{array}{l}\text { Potential } \\
\text { therapeutic } \\
\text { candidate }\end{array}$ & $\begin{array}{l}\text { Authors/ } \\
\text { Refs. }\end{array}$ \\
\hline miR-204 & $\begin{array}{l}\text { Suppressed in } \\
\text { OC tissue }\end{array}$ & $\begin{array}{l}\text { Inhibition of } \\
\text { colony-forming } \\
\text { ability, migration/ } \\
\text { invasion, tumor } \\
\text { size }\end{array}$ & SKOV3 & BDNF & $\begin{array}{l}\downarrow \text { BDNF/TrkB } \\
\text { complex } \\
\downarrow \text { Rac } 1 \text { and actin } \\
\text { reorganization } \\
\downarrow \text { AKT/mTOR }\end{array}$ & $\begin{array}{l}\text { Inhibits lung } \\
\text { metastasis in } \\
\text { SCID mice }\end{array}$ & Yes & $\begin{array}{l}\text { Imam } \\
\text { et al }(93)\end{array}$ \\
\hline $\begin{array}{l}\operatorname{miR}-520 d \\
-3 p\end{array}$ & $\begin{array}{l}\text { Suppressed } \\
\text { in EOC }\end{array}$ & $\begin{array}{l}\text { Inhibition of cell } \\
\text { migration/invasion } \\
\text { and tumor growth }\end{array}$ & $\begin{array}{l}\text { SKOV3ip1/ } \\
\text { HeyA8 }\end{array}$ & EphA2 & $\begin{array}{l}\downarrow \text { EphB2 } \\
\downarrow \text { EphA8 }\end{array}$ & $\begin{array}{l}\text { Inhibits tumor } \\
\text { growth, tumor } \\
\text { weight, cell } \\
\text { proliferation, } \\
\text { angiogenesis } \\
\text { and increase } \\
\text { apoptosis in } \\
\text { SKOV3ip1/ } \\
\text { HeyA8 ortho- } \\
\text { topic model }\end{array}$ & Yes & $\begin{array}{l}\text { Chen } \\
\text { et al (38) }\end{array}$ \\
\hline $\operatorname{miR}-708$ & $\begin{array}{l}\text { Suppressed in } \\
\text { OC tissues }\end{array}$ & $\begin{array}{l}\text { Inhibition of cell } \\
\text { migration/invasion }\end{array}$ & $\begin{array}{l}\text { SKOV3 } \\
\text { SKOVI6iv } \\
\text { TOV112D }\end{array}$ & Rap1B & $\begin{array}{l}\downarrow \text { AKT2 } \\
\downarrow \text { p-FAK } \\
\downarrow \text { p-Paxillin }\end{array}$ & $\begin{array}{l}\text { Inhibits lung } \\
\text { metastasis, } \\
\text { tumor size } \\
\text { in orthotopic } \\
\text { xenograft } \\
\text { mouse model }\end{array}$ & Yes & $\begin{array}{l}\text { Lin } \\
\text { et al (85) }\end{array}$ \\
\hline miR-182 & $\begin{array}{l}\text { Overexpressed } \\
\text { HG-SOC }\end{array}$ & $\begin{array}{l}\text { Inhibition of cell } \\
\text { proliferation, } \\
\text { colony-forming } \\
\text { ability and } \\
\text { migration/invasion }\end{array}$ & $\begin{array}{l}\text { SKOV3 } \\
\text { OVCAR }\end{array}$ & $\begin{array}{l}\text { BRCA1 } \\
\text { FOXO3 } \\
\text { MTSS1 }\end{array}$ & $\begin{array}{l}\uparrow \mathrm{CDKN} 1 \mathrm{~A} \\
\uparrow \mathrm{CDKN} 1 \mathrm{~B} \\
\uparrow \mathrm{CHEK} 2 \\
\uparrow \mathrm{CYLD} \\
\uparrow \mathrm{FOXO1} \\
\uparrow \mathrm{PDCD} 4 \\
\uparrow \mathrm{RECK} \\
\downarrow \mathrm{MYCN} \\
\downarrow \mathrm{HMGA} 2\end{array}$ & $\begin{array}{l}\text { Inhibits tumor } \\
\text { size, invasion } \\
\text { and metastasis } \\
\text { in orthotopic } \\
\text { model }\end{array}$ & Yes & $\begin{array}{l}\mathrm{Xu} \\
\text { et al (129) }\end{array}$ \\
\hline miR-145 & $\begin{array}{l}\text { Suppressed } \\
\text { in EOC and } \\
\text { HG-SOC }\end{array}$ & $\begin{array}{l}\text { Inhibition of cell } \\
\text { proliferation, } \\
\text { colony-forming } \\
\text { ability and } \\
\text { migration/invasion }\end{array}$ & $\begin{array}{l}\text { SKOV3 } \\
\text { HO8910 } \\
\text { OVCAR3 } \\
\text { A2780 }\end{array}$ & $\begin{array}{l}\text { TRIM2 } \\
\text { MTDH }\end{array}$ & $\begin{array}{l}\uparrow \mathrm{BIM} \\
\uparrow \mathrm{TP} 53\end{array}$ & $\begin{array}{l}\text { Inhibits tumor } \\
\text { growth and } \\
\text { metastasis in } \\
\text { xenograft } \\
\text { mouse model }\end{array}$ & Yes & $\begin{array}{l}\text { Dong } \\
\text { et al (108) } \\
\text { Chen } \\
\text { et al (109) }\end{array}$ \\
\hline $\begin{array}{l}\operatorname{miR}-490 \\
-3 p\end{array}$ & $\begin{array}{l}\text { Suppressed } \\
\text { in EOC }\end{array}$ & $\begin{array}{l}\text { Inhibition of cell } \\
\text { proliferation, } \\
\text { apoptosis and } \\
\text { migration/invasion }\end{array}$ & $\begin{array}{l}\text { OVCAR } \\
\text { HO8910-PM }\end{array}$ & CDK1 & $\begin{array}{l}\uparrow \text { TP53 } \\
\downarrow \text { Bcl-xL } \\
\downarrow \text { MMP2/9 } \\
\downarrow \text { CCND1 } \\
\downarrow \text { SMARCD1 }\end{array}$ & $\begin{array}{l}\text { Inhibits tumor } \\
\text { growth and its } \\
\text { development } \\
\text { in xenograft } \\
\text { mouse models }\end{array}$ & Yes & $\begin{array}{l}\text { Chen } \\
\text { et al (99) }\end{array}$ \\
\hline miR-93-5p & $\begin{array}{l}\text { Suppressed in } \\
\text { OC specimens }\end{array}$ & $\begin{array}{l}\text { Inhibition of cell } \\
\text { proliferation, } \\
\text { apoptosis and } \\
\text { migration/invasion }\end{array}$ & $\begin{array}{l}\text { OVCAR } \\
\text { HO8910-PM } \\
\text { SKOV3/ } \\
\text { DDP }\end{array}$ & RhoC & $\begin{array}{l}\uparrow \text { TP53 } \\
\downarrow \text { P70S6K } \\
\downarrow \text { Bcl-xL } \\
\downarrow \text { MMP9 }\end{array}$ & $\begin{array}{l}\text { Inhibits tumor } \\
\text { growth and its } \\
\text { development } \\
\text { in xenograft } \\
\text { mouse models }\end{array}$ & Yes & $\begin{array}{l}\text { Chen } \\
\text { et al (100) }\end{array}$ \\
\hline
\end{tabular}


Table II. Continued.

\begin{tabular}{|c|c|c|c|c|c|c|c|c|}
\hline \multirow[b]{2}{*}{ miRNA } & \multicolumn{8}{|c|}{ Migration, invasion and metastasis } \\
\hline & $\begin{array}{c}\text { Expression } \\
\text { in ovarian } \\
\text { cancer }\end{array}$ & $\begin{array}{l}\text { In vitro } \\
\text { effect }\end{array}$ & $\begin{array}{l}\text { Cancer } \\
\text { cells }\end{array}$ & Target & $\begin{array}{l}\text { Downstream } \\
\text { genes }\end{array}$ & $\begin{array}{l}\text { In vivo } \\
\text { effect }\end{array}$ & $\begin{array}{c}\text { Potential } \\
\text { therapeutic } \\
\text { candidate }\end{array}$ & $\begin{array}{l}\text { Authors/ } \\
\text { Refs. }\end{array}$ \\
\hline $\operatorname{miR}-17$ & $\begin{array}{l}\text { Overexpressed } \\
\text { in OC CD } 44^{+} / \\
\text {CD } 117^{+} \text {stem } \\
\text { cells }\end{array}$ & $\begin{array}{l}\text { Promotes cell } \\
\text { proliferation, } \\
\text { migration/invasion } \\
\text { in CD44\%/ CD } 117^{-} \\
\text {cells }\end{array}$ & $\begin{array}{l}\text { CD } 44^{+} / \\
\text {CD } 117^{+} \\
\text {cells }\end{array}$ & LKB 1 & $\uparrow \mathrm{p} 53-\mathrm{p} 21 / \mathrm{WAF} 1$ & $\begin{array}{l}\text { Promotes } \\
\text { tumor growth } \\
\text { and tumori- } \\
\text { genesis in } \\
\text { CD44/CD } 117^{-} \\
\text {cells }\end{array}$ & Yes & $\begin{array}{l}\text { Liu } \\
\text { et al (101) }\end{array}$ \\
\hline miR-630 & $\begin{array}{l}\text { Overexpressed } \\
\text { in EOC under } \\
\text { hypoxia } \\
\text { conditions }\end{array}$ & $\begin{array}{l}\text { Inhibition of cell } \\
\text { migration/invasion }\end{array}$ & $\begin{array}{l}\text { A2780 } \\
\text { OVCAR3 }\end{array}$ & Dicer & $\begin{array}{l}\uparrow \text { microRNAs } \\
\text { biogenesis }\end{array}$ & $\begin{array}{l}\text { Inhibits tumor } \\
\text { growth and } \\
\text { metastasis } \\
\text { in orthotopic } \\
\text { model }\end{array}$ & Yes & $\begin{array}{l}\text { Rupaimoole } \\
\text { et al (114) }\end{array}$ \\
\hline
\end{tabular}

OC, ovarian cancer; EOC, epithelial ovarian cancer.

eration, migration and invasion in vitro, as well tumor growth in vivo. miR-217 may exert its antitumor effects by targeting the insulin-like growth factor 1 receptor (IGF1R) (117).

MicroRNAs as oncogenes. VEGF is able to stimulate the expression of miRNAs leading to enhanced invasion and metastasis. For instance, Li et al showed that VEGF induced the expression of oncogene miR-205 in OC cells, and this in turn downregulated Ezrin and Lamin A/C. miR-205 promoted invasiveness, proliferation and inhibited apoptosis of $\mathrm{OC}$ cells (118). In addition, the expression levels of VEGF and miR-205 were found increased in the serum of EOC patients (119).

\section{Other microRNAs involved in metastasis}

MicroRNAs functioning as tumor suppressors. Fu et al identified that miR-613, a downregulated miRNA in OC targets the K-RAS oncogene. Congruently, in vivo ectopic expression of miR-613 suppressed cell migration and invasion (120). Likewise, Zhang et al reported that miR-137 is downregulated in EOC and its ectopic expression in vitro decreased cell migration and invasion (121). On the other hand, Shi and Zhang identified that miR-761 expression was severely downregulated in ovarian cancer. Ectopic expression of miR-761 in vitro inhibited invasion by increasing the expression of its target musashi RNA binding protein 1 (MSI1) (122). Yao et al showed that miR-181c was downregulated in OC patients with lymph node metastasis. Restoration of miR-181c expression led to decreased proliferation and metastasis in A2780 cells. Interestingly, protein kinase $\mathrm{C} \delta(\mathrm{PRKC}-\delta)$ was identified as a target of miR-181c and its knockdown in vitro resulted in progression of metastasis (123).

MicroRNAs as oncogenes. Some studies showed that overexpression of miR-25 and miR-181b promotes cell migration and invasion of OC cells by targeting the large tumor suppressor 2
(LATS2). The restoration of LATS2 expression attenuated the oncogenic effects of miR-25 and miR-181b (124,125). Other studies showed that miR-21 repressed PTEN in EOC. Moreover, knockdown of miR-21 significantly inhibited cell proliferation and migration presumably through inhibition of programmed cell death 4 (PDCD4), because PDCD4 was correlated negatively with miR-21 expression $(126,127)$. Wang et al identified that PDCD4 is the target of miR-182. In addition, miR-182 expression induced migration and invasion whereas its silencing inhibited cell viability and colony formation in OC cells due to the recovery of PDCD4 (128).

Likewise, $\mathrm{Xu}$ et al investigated the therapeutic potential of miR-182 in orthotopic model using SKOV3 (intrabursal xenografts) and OVCAR3 (intraperitoneal injection) cancer cells. Overexpression of miR-182 was associated with metastatic HG-SOC. The treatment with miR-182 inhibitors restored the expression of breast cancer 1 (BRCA1), FOXO3, metastasis suppressor 1 (MTSS1) and other genes involved in cell cycle control. All these tumor suppressor genes were miR-182 targets and their inhibition resulted in increased tumor growth, invasion and metastasis. Anti-miR-182 treatment restored the gene expression of their targets, which in turn reduced tumor invasion and metastasis in a model of SOC (129). In addition, Liu et al found that overexpression of miR-182 in immortalized ovarian surface cells; fallopian tube secretory cells and malignant ovarian cells lead to promotion of invasiveness and metastasis in female BALB/c nude mice. Oncogenic effects of miR-182 were driven by downregulation of BRCA1 and MTSS1, as well as overexpression of HMGA2 (130).

Nakayama et al showed that loss of homeobox D10 (HOXD10) gene due to overexpression of miR-10b enhanced the migration and invasion through increased activity of the pro-metastatic genes MMP14 and RhoC (131). Fan et al established that the inhibition of miR-20a suppresses the invasion by targeting amyloid precursor protein (APP) in OC (132). Similarly, Zou et al found that overexpression of miR-197 
promotes the invasion of cancer cells through downregulation of its target nemo-like kinase (NLK) (133).

\section{Possible exploitation of microRNAs in precision medicine}

There is increased evidence that miRNAs play crucial roles as innovative therapeutic targets in OC. Due to their extreme stability and its potent activities that allow modulating relevant gene networks impacting tumor biology, miRNAs has also been studied as a prospective antitumor approach. The miRNAs can limit tumor growth and dissemination of tumor cells. These effects can be induced by inactivating oncogenic miRNAs or restoring the expression of miRNAs with tumor suppressor functions (134). The potential usefulness of a miRNA-based therapy has been exploited by different approaches such as: i) antisense oligonucleotides and synthetic analogues of miRNAs (antagomirs) to silence oncogenic miRNAs $(135,136)$; and ii) synthetic miRNAs (mimics), chemically modified oligonucleotides or adeno-associated virus-based vector system to restore the expression of downregulated tumor suppressive miRNAs $(137,138)$. Garzon et al showed that the effects of upregulated oncomiRs could be suppressed using antagomirs (139). For instance, Lu et al using a modified anti-miRNA antisense olideoxyribonucleotide (AMOs) revealed that the use of this innovative strategy silenced multiple-target miRNAs. This technology was used to targets oncogenic miR-21, miR-155, and miR-17-5 (140). In other report, Dai et al showed that using a chimera composed by a mucin 1 (MUC1) aptamer targeting the tumor cell surface MUC1 protein and miR-29b mimics inhibiting DNA methyltransferases, resulted in the expression of PTEN tumor suppressor. Interestingly, these findings provide evidence that delivery of miRNAs in a tissue-specific manner is possible and that it may exert potent antitumor effects (141). Another example of application of miRNAs as therapeutic tools is the miR-200 family. Restoration of miR-200c in combination with paclitaxel treatment decreased tumor development. miR-200c therapy before conventional chemotherapy reduces the effective dose of drugs resulting in increased response (142). Other miRNAs involved in cellular mechanisms that promote the development and progression of metastasis in OC have tumor suppressive effects when delivered in vivo into experimental models. For instance, miR-200c, miR-506, miR-203, miR-373, miR-138, miR-181a and miR-155 gained attention by suppressing EMT process and metastasis. In Tables I and II the miRNAs that have showed efficacy in decreasing the metastasis of tumor cells and that target EMT with potential clinical applications are listed. Such miRNAs are potential candidates for translational medicine in $\mathrm{OC}$ therapies (143).

\section{Conclusion}

The recent discovery of the role of miRNAs as tumorsuppressor genes and oncogenes has added an additional level of complexity to the mechanisms leading to tumorigenesis. The identification of miRNAs involved in invasion and metastasis will provide insights into molecular mechanisms underlying tumorigenesis. These miRNAs could be useful as clinical strategies to customize therapeutic targets that act in spatial and temporal manner during malignancy progression and metastasis in ovarian cancer. The updated review presented here, showed that metastamiRs have emerged as new molecular players to regulate invasion and metastasis events in ovarian cancer. Some of these miRNAs are common regulators of cell motility and invasion in distinct types of cancers while others appear to be cancer specific. Understanding how metastamiRs are involved in regulating tumor invasion and metastasis processes will provide data to establish potential strategies for the development of new metastamiR-based treatments. However, further investigations and clinical trials challenging the potential applications of metastamiRs are required in order to use them as targets for personalized therapies, prognosis and diagnosis in the near future.

\section{Acknowledgements}

This study was supported by CONACyT (grant nos. 233370 and 222335). The funders had no role in study design, data collection and analysis, decision to publish, or preparation of the manuscript.

\section{References}

1. Vaughan S, Coward JI, Bast RC Jr, Berchuck A, Berek JS, Brenton JD,Coukos G,Crum CC,Drapkin R,EtemadmoghadamD, et al: Rethinking ovarian cancer: Recommendations for improving outcomes. Nat Rev Cancer 11: 719-725, 2011.

2. Ledermann JA, Marth C, Carey MS, Birrer M, Bowtell DD, Kaye S, McNeish I, Oza A, Scambia G, Rustin G, et al; Gynecologic Cancer InterGroup: Role of molecular agents and targeted therapy in clinical trials for women with ovarian cancer. Int J Gynecol Cancer 21: 763-770, 2011.

3. Kim VN: MicroRNA biogenesis: Coordinated cropping and dicing. Nat Rev Mol Cell Biol 6: 376-385, 2005.

4. Nguyen DX, Bos PD and Massagué J: Metastasis: From dissemination to organ-specific colonization. Nat Rev Cancer 9: 274-284, 2009.

5. Lopez-Camarillo C, Marchat LA, Arechaga-Ocampo E Perez-Plasencia C, Del Moral-Hernandez O, Castaneda-Ortiz EJ and Rodriguez-Cuevas S: MetastamiRs: Non-coding MicroRNAs driving cancer invasion and metastasis. Int J Mol Sci 13: 1347-1379, 2012.

6. White NM, Fatoohi E, Metias M, Jung K, Stephan C and Yousef GM: Metastamirs: A stepping stone towards improved cancer management. Nat Rev Clin Oncol 8: 75-84, 2011.

7. Cai $\mathrm{X}$, Hagedorn $\mathrm{CH}$ and Cullen BR: Human microRNAs are processed from capped, polyadenylated transcripts that can also function as mRNAs. RNA 10: 1957-1966, 2004.

8. Lee Y, Ahn C, Han J, Choi H, Kim J, Yim J, Lee J, Provost P, Rådmark O, Kim S, et al: The nuclear RNase III Drosha initiates microRNA processing. Nature 425: 415-419, 2003.

9. Vasudevan S, Tong Y and Steitz JA: Switching from repression to activation: microRNAs can up-regulate translation. Science 318: 1931-1934, 2007.

10. Eulalio A, Behm-Ansmant I and Izaurralde E: P bodies: At the crossroads of post-transcriptional pathways. Nat Rev Mol Cell Biol 8: 9-22, 2007.

11. Sen GL and Blau HM: Argonaute 2/RISC resides in sites of mammalian mRNA decay known as cytoplasmic bodies. Nat Cell Biol 7: 633-636, 2005.

12. Esquela-Kerscher A and Slack FJ: Oncomirs - microRNAs with a role in cancer. Nat Rev Cancer 6: 259-269, 2006.

13. Zhang B, Pan X, Cobb GP and Anderson TA: microRNAs as oncogenes and tumor suppressors. Dev Biol 302: 1-12, 2007.

14. Nishimura M, Jung E-J, Shah MY, Lu C, Spizzo R, Shimizu M, Han HD, Ivan C, Rossi S, Zhang X, et al: Therapeutic synergy between microRNA and siRNA in ovarian cancer treatment. Cancer Discov 3: 1302-1315, 2013.

15. Wang L, Mezencev R, Švajdler M, Benigno BB and McDonald JF: Ectopic over-expression of miR-429 induces mesenchymal-toepithelial transition (MET) and increased drug sensitivity in metastasizing ovarian cancer cells. Gynecol Oncol 134: 96-103, 2014. 
16. Micalizzi DS, Farabaugh SM and Ford HL: Epithelialmesenchymal transition in cancer: Parallels between normal development and tumor progression. J Mammary Gland Biol Neoplasia 15: 117-134, 2010.

17. Corallino S, Malabarba MG, Zobel M, Di Fiore PP and Scita G: Epithelial-to-mesenchymal plasticity harnesses endocytic circuitries. Front Oncol 5: 45, 2015.

18. Oskarsson T, Batlle E and Massagué J: Metastatic stem cells: Sources, niches, and vital pathways. Cell Stem Cell 14: 306-321, 2014.

19. Kalluri R and Weinberg RA: The basics of epithelial-mesenchymal transition. J Clin Invest 119: 1420-1428, 2009.

20. Garg M: Targeting microRNAs in epithelial-to-mesenchymal transition-induced cancer stem cells: Therapeutic approaches in cancer. Expert Opin Ther Targets 19: 285-297, 2015.

21. Abba ML, Patil N, Leupold JH and Allgayer H: MicroRNA regulation of epithelial to mesenchymal transition. J Clin Med 5: 8, 2016

22. Huber MA, Kraut $\mathrm{N}$ and Beug $\mathrm{H}$ : Molecular requirements for epithelial-mesenchymal transition during tumor progression. Curr Opin Cell Biol 17: 548-558, 2005.

23. Heuberger $\mathbf{J}$ and Birchmeier W: Interplay of cadherin-mediated cell adhesion and canonical Wnt signaling. Cold Spring Harb Perspect Biol 2: a002915, 2010.

24. Arend RC,Londoño-Joshi AI, Straughn JM Jr and Buchsbaum DJ: The Wnt/ $\beta$-catenin pathway in ovarian cancer: A review. Gynecol Oncol 131: 772-779, 2013

25. Ke Z, Caiping S, Qing Z and Xiaojing W: Sonic hedgehog-Gli1 signals promote epithelial-mesenchymal transition in ovarian cancer by mediating PI3K/AKT pathway. Med Oncol 32: 368, 2015.

26. Fang D, Chen H, Zhu JY, Wang W, Teng Y, Ding HF, Jing Q, Su SB and Huang S: Epithelial-mesenchymal transition of ovarian cancer cells is sustained by Racl through simultaneous activation of MEK1/2 and Src signaling pathways. Oncogene Sep 12, 2016 (Epub ahead of print). doi: 10.1038/onc.2016.323.

27. Talbot LJ, Bhattacharya SD and Kuo PC: Epithelial-mesenchymal transition, the tumor microenvironment, and metastatic behavior of epithelial malignancies. Int J Biochem Mol Biol 3: 117-136, 2012

28. Fuxe J, Vincent $\mathrm{T}$ and Garcia de Herreros A: Transcriptional crosstalk between TGF- $\beta$ and stem cell pathways in tumor cel invasion: Role of EMT promoting Smad complexes. Cell Cycle 9: 2363-2374, 2010

29. Moustakas A and Heldin $\mathrm{CH}$ : Signaling networks guiding epithelial-mesenchymal transitions during embryogenesis and cancer progression. Cancer Sci 98: 1512-1520, 2007.

30. Gibbons DL, Lin W, Creighton CJ, Rizvi ZH, Gregory PA, Goodall GJ, Thilaganathan N, Du L, Zhang Y, Pertsemlidis A et al: Contextual extracellular cues promote tumor cell EMT and metastasis by regulating miR-200 family expression. Genes Dev 23: $2140-2151,2009$

31. Gregory PA, Bert AG, Paterson EL, Barry SC, Tsykin A, Farshid G, Vadas MA, Khew-Goodall Y and Goodall GJ: The miR-200 family and miR-205 regulate epithelial to mesenchymal transition by targeting ZEB1 and SIP1. Nat Cell Biol 10: 593-601, 2008

32. Korpal M,Lee ES, Hu G and Kang Y: The miR-200 family inhibits epithelial-mesenchymal transition and cancer cell migration by direct targeting of E-cadherin transcriptional repressors ZEB1 and ZEB2. J Biol Chem 283: 14910-14914, 2008.

33. Park SM, Gaur AB, Lengyel E and Peter ME: The miR-200 family determines the epithelial phenotype of cancer cells by targeting the E-cadherin repressors ZEB1 and ZEB2. Genes Dev 22: 894-907, 2008

34. Bendoraite A, Knouf EC, Garg KS, Parkin RK, Kroh EM, O'Briant KC, Ventura AP, Godwin AK, Karlan BY, Drescher CW, et al: Regulation of miR-200 family microRNAs and ZEB transcription factors in ovarian cancer: Evidence supporting a mesothelial-to-epithelial transition. Gynecol Oncol 116: 117-125, 2010.

35. Chen J, Wang L, Matyunina LV, Hill CG and McDonald JF: Overexpression of miR-429 induces mesenchymal-to-epithelial transition (MET) in metastatic ovarian cancer cells. Gynecol Oncol 121: 200-205, 2011.

36. Jabbari N, Reavis AN and McDonald JF: Sequence variation among members of the miR-200 microRNA family is correlated with variation in the ability to induce hallmarks of mesenchymalepithelial transition in ovarian cancer cells. J Ovarian Res 7: 12 2014.

37. Lu YM, Shang C, Ou YL, Yin D, Li YN, Li X, Wang N and Zhang SL: miR-200c modulates ovarian cancer cell metastasis potential by targeting zinc finger E-box-binding homeobox 2 (ZEB2) expression. Med Oncol 31: 134, 2014.
38. Chen D, Zhang Y, Wang J, Chen J, Yang C, Cai K, Wang X, Shi F and Dou J: MicroRNA-200c overexpression inhibits tumorigenicity and metastasis of $\mathrm{CD} 117^{+} \mathrm{CD} 44^{+}$ovarian cancer stem cells by regulating epithelial-mesenchymal transition. J Ovarian Res 6: 50,2013

39. Wang Y, Yan S, Liu X, Zhang W, Li Y, Dong R, Zhang Q, Yang Q, Yuan C, Shen K, et al: miR-1236-3p represses the cell migration and invasion abilities by targeting ZEB1 in high-grade serous ovarian carcinoma. Oncol Rep 31: 1905-1910, 2014.

40. Wu Q, Guo R, Lin M, Zhou B and Wang Y: MicroRNA-200a inhibits $\mathrm{CD} 133 / 1^{+}$ovarian cancer stem cells migration and invasion by targeting E-cadherin repressor ZEB2. Gynecol Oncol 122: 149-154, 2011.

41. Vang S, Wu HT, Fischer A, Miller DH, MacLaughlan S, Douglass E, Comisar L, Steinhoff M, Collins C, Smith PJ, et al: Identification of ovarian cancer metastatic miRNAs. PLoS One 8: e58226, 2013.

42. Jin M, Yang Z, Ye W, Xu H and Hua X: MicroRNA-150 predicts a favorable prognosis in patients with epithelial ovarian cancer, and inhibits cell invasion and metastasis by suppressing transcriptional repressor ZEB1. PLoS One 9: e103965, 2014.

43. Chen Y, Luo J, Tian R, Sun H and Zou S: miR-373 negatively regulates methyl-CpG-binding domain protein 2 (MBD2) in hilar cholangiocarcinoma. Dig Dis Sci 56: 1693-1701, 2011

44. Oppenheimer H, Kumar A, Meir H, Schwartz I, Zini A, Haze A, Kandel L, Mattan Y, Liebergall M and Dvir-Ginzberg M: Set7/9 impacts COL2A1 expression through binding and repression of SirT1 histone deacetylation. J Bone Miner Res 29: 348-360, 2014.

45. Zhou J, Xie M, Shi Y, Luo B, Gong G, Li J, Wang J, Zhao W, Zi Y, Wu X, et al: MicroRNA-153 functions as a tumor suppressor by targeting SET7 and ZEB2 in ovarian cancer cells. Oncol Rep 34: 111-120, 2015.

46. Kim YS, Yi BR, Kim NH and Choi KC: Role of the epithelialmesenchymal transition and its effects on embryonic stem cells. Exp Mol Med 46: e108, 2014.

47. Yang D, Sun Y, Hu L, Zheng H, Ji P, Pecot CV, Zhao Y, Reynolds S, Cheng H, Rupaimoole R, et al: Integrated analyses identify a master microRNA regulatory network for the mesenchymal subtype in serous ovarian cancer. Cancer Cell 23: 186-199, 2013.

48. Sun Y, Mezzanzanica D and Zhang W: MiR-506: A Multitasker in suppression of the epithelial-to-mesenchymal transition. RNA Dis 1: e 447, 2014.

49. Sun Y, Hu L, Zheng H, Bagnoli M, Guo Y, Rupaimoole R, Rodriguez-Aguayo C, Lopez-Berestein G, Ji P, Chen K, et al: MiR-506 inhibits multiple targets in the epithelial-to-mesenchymal transition network and is associated with good prognosis in epithelial ovarian cancer. J Pathol 235: 25-36, 2015.

50. Zhao G, Guo Y, Chen Z, Wang Y, Yang C, Dudas A, Du Z, Liu W, Zou Y, Szabo E, et al: miR-203 functions as a tumor suppressor by inhibiting epithelial to mesenchymal transition in ovarian cancer. J Cancer Sci Ther 7: 34-43, 2015.

51. Ye Z, Zhao L, Li J, Chen W and Li X: miR-30d blocked transforming growth factor $\beta 1$-induced epithelial-mesenchymal transition by targeting Snail in ovarian cancer cells. Int J Gynecol Cancer 25: 1574-1581, 2015.

52. Siemens H, Jackstadt R, Hünten S, Kaller M, Menssen A, Götz U and Hermeking H: miR-34 and SNAIL form a double-negative feedback loop to regulate epithelial-mesenchymal transitions. Cell Cycle 10: 4256-4271, 2011.

53. Su JL, Chen PB, Chen YH, Chen SC, Chang YW, Jan YH, Cheng X, Hsiao M and Hung MC: Downregulation of microRNA miR-520h by E1A contributes to anticancer activity. Cancer Res 70: 5096-5108, 2010.

54. Wu J and Wei JJ: HMGA2 and high-grade serous ovarian carcinoma. J Mol Med (Berl) 91: 1155-1165, 2013.

55. Wu J, Liu Z, Shao C, Gong Y, Hernando E, Lee P, Narita M, Muller W, Liu J and Wei JJ: HMGA2 overexpression-induced ovarian surface epithelial transformation is mediated through regulation of EMT genes. Cancer Res 71: 349-359, 2011.

56. Tanaka T, Arai M, Wu S, Kanda T, Miyauchi H, Imazeki F, Matsubara $\mathrm{H}$ and Yokosuka O: Epigenetic silencing of microRNA-373 plays an important role in regulating cell proliferation in colon cancer. Oncol Rep 26: 1329-1335, 2011.

57. Zhang Y, Zhao FJ, Chen LL, Wang LQ, Nephew KP, Wu YL and Zhang S: MiR-373 targeting of the Rab22a oncogene suppresses tumor invasion and metastasis in ovarian cancer. Oncotarget 5: 12291-12303, 2014.

58. Hsiao CP, Araneta M, Wang XM and Saligan LN: The association of IFI27 expression and fatigue intensification during localized radiation therapy: Implication of a para-inflammatory bystander response. Int J Mol Sci 14: 16943-16957, 2013. 
59. Li S, Xie Y, Zhang W, Gao J, Wang M, Zheng G, Yin X, Xia H and Tao X: Interferon alpha-inducible protein 27 promotes epithelialmesenchymal transition and induces ovarian tumorigenicity and stemness. J Surg Res 193: 255-264, 2015.

60. Baskar S, Wiestner A, Wilson WH, Pastan I and Rader C: Targeting malignant $\mathrm{B}$ cells with an immunotoxin against ROR1. MAbs 4: 349-361, 2012.

61. Tan H, He Q, Gong G, Wang Y, Li J, Wang J, Zhu D and Wu X: miR-382 inhibits migration and invasion by targeting ROR through regulating EMT in ovarian cancer. Int J Oncol 48 181-190, 2016

62. Yeh YM, Chuang CM, Chao KC and Wang LH: MicroRNA-138 suppresses ovarian cancer cell invasion and metastasis by targeting SOX4 and HIF-1 $\alpha$. Int J Cancer 133: 867-878, 2013.

63. Cowden Dahl KD, Dahl R, Kruichak JN and Hudson LG: The epidermal growth factor receptor responsive miR-125a represses mesenchymal morphology in ovarian cancer cells. Neoplasia 11: $1208-1215,2009$

64. Bobbs A, Gellerman K, Hallas WM, Joseph S, Yang C, Kurkewich J and Cowden Dahl KD: ARID3B directly regulates ovarian cancer promoting genes. PLoS One 10: e0131961, 2015.

65. Zhou X, Hu Y, Dai L, Wang Y, Zhou J, Wang W, Di W and Qiu L: MicroRNA-7 inhibits tumor metastasis and reverses epithelialmesenchymal transition through AKT/ERK1/2 inactivation by targeting EGFR in epithelial ovarian cancer. PLoS One 9: e96718, 2014

66. Yuan ZQ, Sun M,Feldman RI, Wang G, Ma X, Jiang C, Coppola D Nicosia SV and Cheng JQ: Frequent activation of AKT2 and induction of apoptosis by inhibition of phosphoinositide-3-OH kinase/Akt pathway in human ovarian cancer. Oncogene 19: 2324-2330, 2000.

67. Luo X, Dong Z, Chen Y, Yang L and Lai D: Enrichment of ovarian cancer stem-like cells is associated with epithelial to mesenchymal transition through an miRNA-activated AKT pathway. Cell Prolif 46: 436-446, 2013

68. Parikh A, Lee C, Joseph P, Marchini S, Baccarini A, Kolev V, Romualdi C, Fruscio R, Shah H, Wang F, et al: microRNA-181a has a critical role in ovarian cancer progression through the regulation of the epithelial-mesenchymal transition. Nat Commun 5: 2977,2014

69. Fang L, Li H, Wang L, Hu J, Jin T, Wang J and Yang BB MicroRNA-17-5p promotes chemotherapeutic drug resistance and tumour metastasis of colorectal cancer by repressing PTEN expression. Oncotarget 5: 2974-2987, 2014.

70. Fang Y, Xu C and Fu Y: MicroRNA-17-5p induces drug resistance and invasion of ovarian carcinoma cells by targeting PTEN signaling. J Biol Res (Thessalon) 22: 12, 2015.

71. Qin W, Ren Q, Liu T, Huang Y and Wang J: MicroRNA-155 is a novel suppressor of ovarian cancer-initiating cells that targets CLDN1. FEBS Lett 587: 1434-1439, 2013

72. Iorio MV, Visone R, Di Leva G, Donati V, Petrocca F, Casalini P, Taccioli C, Volinia S, Liu CG, Alder H, et al: MicroRNA signatures in human ovarian cancer. Cancer Res 67: 8699-8707, 2007.

73. Habata S, Iwasaki M, Sugio A, Suzuki M, Tamate M, Satohisa S, Tanaka R and Saito T: BAG3 increases the invasiveness of uterine corpus carcinoma cells by suppressing miR-29b and enhancing MMP2 expression. Oncol Rep 33: 2613-2621, 2015.

74. Sun X, Cui M, Zhang A, Tong L, Wang K, Li K, Wang X, Sun Z and Zhang H: MiR-548c impairs migration and invasion of endometrial and ovarian cancer cells via downregulation of Twist. J Exp Clin Cancer Res 35: 10, 2016.

75. Su N, Qiu H, Chen Y, Yang T, Yan Q and Wan X: miR-205 promotes tumor proliferation and invasion through targeting ESRRG in endometrial carcinoma. Oncol Rep 29: 2297-2302, 2013.

76. Mozos A, Catasús L, D'Angelo E, Serrano E, Espinosa I, Ferrer I, Pons $\mathrm{C}$ and Prat J: The FOXO1-miR27 tandem regulates myometrial invasion in endometrioid endometrial adenocarcinoma. Hum Pathol 45: 942-951, 2014.

77. Dong M, Yang P and Hua F: MiR-191 modulates malignant transformation of endometriosis through regulating TIMP3. Med Sci Monit 21: 915-920, 2015

78. Li S, Hu R, Wang C, Guo F, Li X and Wang S: miR-22 inhibits proliferation and invasion in estrogen receptor $\alpha$-positive endometrial endometrioid carcinomas cells. Mol Med Rep 9: 2393-2399, 2014

79. Chen X, Yan Q, Li S, Zhou L, Yang H, Yang Y, Liu X and Wan X: Expression of the tumor suppressor miR-206 is associated with cellular proliferative inhibition and impairs invasion in ER $\alpha$-positive endometrioid adenocarcinoma. Cancer Lett 314: 41-53, 2012 .
80. Li S, Li Y, Wen Z, Kong F, Guan X and Liu W: microRNA-206 overexpression inhibits cellular proliferation and invasion of estrogen receptor $\alpha$-positive ovarian cancer cells. Mol Med Rep 9: 1703-1708, 2014

81. Liang SH, Li J, Al-beit M, Zhang J, Ma D and Lu X: Screening and identification of potential miRNA involved in ovarian cancer invasion and metastasis. Zhonghua Zhong Liu Za Zhi 32: 650-654, 2010 (In Chinese).

82.Li J, Liang S, Yu H, Zhang J, Ma D and Lu X: An inhibitory effect of miR-22 on cell migration and invasion in ovarian cancer. Gynecol Oncol 119: 543-548, 2010.

83. Li J, Liang S, Jin H, Xu C, Ma D and Lu X: Tiam1, negatively regulated by miR-22, miR-183 and miR-31, is involved in migration, invasion and viability of ovarian cancer cells. Oncol Rep 27: 1835-1842, 2012.

84. Wen C, Liu X, Ma H, Zhang W and Li H: miR-338-3p suppresses tumor growth of ovarian epithelial carcinoma by targeting Runx2. Int J Oncol 46: 2277-2285, 2015.

85. Lin K-T, Yeh Y-M, Chuang C-M, Yang SY, Chang JW, Sun SP, Wang YS, Chao KC and Wang LH: Glucocorticoids mediate induction of microRNA-708 to suppress ovarian cancer metastasis through targeting Rap1B. Nat Commun 6: 5917, 2015.

86. Zhang H, Wang Q, Zhao Q and Di W: MiR-124 inhibits the migration and invasion of ovarian cancer cells by targeting SphK1. J Ovarian Res 6: 84, 2013.

87. Wen Z, Zhao S, Liu S, Liu Y, Li X and Li S: MicroRNA-148a inhibits migration and invasion of ovarian cancer cells via targeting sphingosine-1-phosphate receptor 1. Mol Med Rep 12: 3775-3780, 2015.

88. Chen P, Zeng M, Zhao Y and Fang X: Upregulation of Limk1 caused by microRNA-138 loss aggravates the metastasis of ovarian cancer by activation of Limk1/cofilin signaling. Oncol Rep 32: 2070-2076, 2014

89. Wang W, Ren F, Wu Q, Jiang D, Li H, Peng Z, Wang J and Shi H: MicroRNA-497 inhibition of ovarian cancer cell migration and invasion through targeting of SMAD specific E3 ubiquitin protein ligase 1. Biochem Biophys Res Commun 449: 432-437, 2014

90. Lee M, Kim EJ and Jeon MJ: MicroRNAs 125a and 125b inhibit ovarian cancer cells through post-transcriptional inactivation of EIF4EBP1. Oncotarget 7: 8726-8742, 2016.

91. Meng X, Joosse SA, Müller V, Trillsch F, Milde-Langosch K, Mahner S, Geffken M, Pantel K and Schwarzenbach $\mathrm{H}$ : Diagnostic and prognostic potential of serum miR-7, miR-16, miR-25, miR-93, miR-182, miR-376a and miR-429 in ovarian cancer patients. Br J Cancer 113: 1358-1366, 2015.

92. Cao J, Cai J, Huang D, Han Q, Yang Q, Li T, Ding H and Wang Z: miR-335 represents an invasion suppressor gene in ovarian cancer by targeting Bcl-w. Oncol Rep 30: 701-706, 2013.

93. Imam JS, Plyler JR, Bansal H, Prajapati S, Bansal S, Rebeles J, Chen HI, Chang YF, Panneerdoss S, Zoghi B, et al: Genomic loss of tumor suppressor miRNA-204 promotes cancer cell migration and invasion by activating AKT/mTOR/Rac1 signaling and actin reorganization. PLoS One 7: e52397, 2012.

94. Chung TK, Lau TS, Cheung TH, Yim SF, Lo KW, Siu NS Chan LK, Yu MY, Kwong J, Doran G, et al: Dysregulation of microRNA-204 mediates migration and invasion of endometrial cancer by regulating FOXC1. Int J Cancer 130: 1036-1045, 2012

95. Vimalraj S, Miranda PJ, Ramyakrishna B and Selvamurugan N Regulation of breast cancer and bone metastasis by microRNAs Dis Markers 35: 369-387, 2013.

96. Tang H, Yao L, Tao X, Yu Y, Chen M, Zhang R and Xu C: miR-9 functions as a tumor suppressor in ovarian serous carcinoma by targeting TLN1. Int J Mol Med 32: 381-388, 2013.

97. Ohyagi-Hara C, Sawada K, Kamiura S, Tomita Y, Isobe A Hashimoto K, Kinose Y, Mabuchi S, Hisamatsu T, Takahashi T, et al: miR-92a inhibits peritoneal dissemination of ovarian cancer cells by inhibiting integrin $\alpha 5$ expression. Am J Pathol 182: 1876-1889, 2013.

98. Doberstein K, Bretz NP, Schirmer U, Fiegl H, Blaheta R Breunig C, Müller-Holzner E, Reimer D, Zeimet AG and Altevogt P: miR-21-3p is a positive regulator of L1CAM in several human carcinomas. Cancer Lett 354: 455-466, 2014

99. Chen S, Chen X, Xiu YL, Sun KX and Zhao Y: MicroRNA-490-3P targets CDK1 and inhibits ovarian epithelial carcinoma tumorigenesis and progression. Cancer Lett 362: 122-130, 2015.

100. Chen X, Chen S, Xiu Y-L, Sun K-X, Zong Z-H and Zhao Y: RhoC is a major target of microRNA-93-5P in epithelial ovarian carcinoma tumorigenesis and progression. Mol Cancer 14: 31, 2015 . 
101. Liu T, Qin W, Hou L and Huang Y: MicroRNA-17 promotes normal ovarian cancer cells to cancer stem cells development via suppression of the LKB1-p53-p21/WAF1 pathway. Tumour Biol 36: 1881-1893, 2015.

102. Corney DC, Hwang CI, Matoso A, Vogt M, Flesken-Nikitin A, Godwin AK, Kamat AA, Sood AK, Ellenson LH, Hermeking H, et al: Frequent downregulation of miR-34 family in human ovarian cancers. Clin Cancer Res 16: 1119-1128, 2010.

103. Hwang C-I, Choi J, Zhou Z, Flesken-Nikitin A, Tarakhovsky A and Nikitin AY: MET-dependent cancer invasion may be preprogrammed by early alterations of p53-regulated feedforward loop and triggered by stromal cell-derived HGF. Cell Cycle 10: 3834-3840, 2011

104. Hwang C-I, Matoso A, Corney DC, Flesken-Nikitin A, Körner S, Wang W, Boccaccio C, Thorgeirsson SS, Comoglio PM, Hermeking $\mathrm{H}$, et al: Wild-type p53 controls cell motility and invasion by dual regulation of MET expression. Proc Natl Acad Sci USA 108: 14240-14245, 2011.

105. Li R, Shi X, Ling F, Wang C, Liu J, Wang W and Li M: MiR-34a suppresses ovarian cancer proliferation and motility by targeting AXL. Tumour Biol 36: 7277-7283, 2015.

106. Wu H, Xiao Z, Wang K, Liu W and Hao Q: MiR-145 is downregulated in human ovarian cancer and modulates cell growth and invasion by targeting p70S6K1 and MUC1. Biochem Biophys Res Commun 441: 693-700, 2013.

107. Ahmed AA, Etemadmoghadam D, Temple J, Lynch AG, Riad M, Sharma R, Stewart C, Fereday S, Caldas C, Defazio A, et al: Driver mutations in TP53 are ubiquitous in high grade serous carcinoma of the ovary. J Pathol 221: 49-56, 2010

108. Dong R, Liu X, Zhang Q, Jiang Z, Li Y, Wei Y, Li Y, Yang Q, Liu J, Wei JJ, et al: miR-145 inhibits tumor growth and metastasis by targeting metadherin in high-grade serous ovarian carcinoma. Oncotarget 5: 10816-10829, 2014.

109. Chen X, Dong C, Law PT, Chan MT, Su Z, Wang S, Wu WK and Xu H: MicroRNA-145 targets TRIM2 and exerts tumorsuppressing functions in epithelial ovarian cancer. Gynecol Oncol 139: 513-519, 2015.

110. Kim TH, Song JY, Park H, Jeong JY, Kwon AY, Heo JH, Kang H, Kim G and An HJ: miR-145, targeting high-mobility group A2, is a powerful predictor of patient outcome in ovarian carcinoma. Cancer Lett 356B: 937-945, 2015.

111. Yan L, Zhou J, Gao Y, Ghazal S, Lu L, Bellone S, Yang Y, Liu N, Zhao X, Santin AD, et al: Regulation of tumor cell migration and invasion by the H19/let-7 axis is antagonized by metformininduced DNA methylation. Oncogene 34: 3076-3084, 2015.

112. Gao Y, Meng H, Liu S, Hu J, Zhang Y, Jiao T, Liu Y, Ou J, Wang D, Yao L, et al: LncRNA-HOST2 regulates cell biological behaviors in epithelial ovarian cancer through a mechanism involving microRNA let-7b. Hum Mol Genet 24: 841-852, 2015.

113. Guo Y, Tian P, Yang C, Liang Z, Li M, Sims M, Lu L, Zhang Z, Li H, Pfeffer LM, et al: Silencing the double-stranded RNA binding protein DGCR8 inhibits ovarian cancer cell proliferation, migration, and invasion. Pharm Res 32: 769-778, 2015.

114. Rupaimoole R, Ivan C, Yang D, Gharpure KM, Wu SY, Pecot CV, Previs RA, Nagaraja AS, Armaiz-Pena GN, McGuire M, et al: Hypoxia-upregulated microRNA-630 targets Dicer, leading to increased tumor progression. Oncogene 35: 4312-4320, 2016.

115. Tang R, Cui ZM and Lou YH: MicroRNA-16 regulates the proliferation, invasion and apoptosis of ovarian epithelial carcinoma cells in vitro. Zhonghua Fu Chan Ke Za Zhi 47: 846-850, 2012 (In Chinese)

116. Wei LQ, Liang HT, Qin DC, Jin HF, Zhao Y and She MC: MiR-212 exerts suppressive effect on SKOV3 ovarian cancer cells through targeting HBEGF. Tumour Biol 35: 12427-12434, 2014.

117. Li J, Li D and Zhang W: Tumor suppressor role of miR-217 in human epithelial ovarian cancer by targeting IGF1R. Oncol Rep 35: 1671-1679, 2016.

118. Li J, Li L, Li Z, Gong G, Chen P, Liu H, Wang J, Liu Y and Wu X: The role of miR-205 in the VEGF-mediated promotion of human ovarian cancer cell invasion. Gynecol Oncol 137: 125-133, 2015.

119. Zhou J, Liu H, Chen Y, Wen J, Li L and Wu X: Expression and significance of VEGF, miR-205 and target protein Ezrin and Lamin A/C in ovarian cancer. Zhong Nan Da Xue Xue Bao Yi Xue Ban 39: 142-150, 20140 (In Chinese).

120.Fu X, Cui Y, Yang S, Xu Y and Zhang Z: MicroRNA-613 inhibited ovarian cancer cell proliferation and invasion by regulating KRAS. Tumour Biol 37: 6477-6483, 2016.

121. Zhang L, Li Z, Gai F and Wang Y: MicroRNA-137 suppresses tumor growth in epithelial ovarian cancer in vitro and in vivo. Mol Med Rep 12: 3107-3114, 2015.
122. Shi $\mathrm{C}$ and Zhang Z: miR-761 inhibits tumor progression by targeting MSI1 in ovarian carcinoma. Tumour Biol 37: 5437-5443, 2016.

123. Yao L, Wang L, Li F, Gao X, Wei X and Liu Z: MiR181c inhibits ovarian cancer metastasis and progression by targeting PRKCD expression. Int J Clin Exp Med 8: 15198-15205, 2015.

124. Feng S, Pan W, Jin Y and Zheng J: MiR-25 promotes ovarian cancer proliferation and motility by targeting LATS2. Tumour Biol 35: 12339-12344, 2014

125. Xia Y and Gao Y: MicroRNA-181b promotes ovarian cancer cell growth and invasion by targeting LATS2. Biochem Biophys Res Commun 447: 446-451, 2014.

126. Lou Y, Yang X, Wang F, Cui Z and Huang Y: MicroRNA-21 promotes the cell proliferation, invasion and migration abilities in ovarian epithelial carcinomas through inhibiting the expression of PTEN protein. Int J Mol Med 26: 819-827, 2010.

127. Lou Y, Cui Z, Wang F, Yang X and Qian J: miR-21 down-regulation promotes apoptosis and inhibits invasion and migration abilities of OVCAR3 cells. Clin Invest Med 34: E281, 2011.

128. Wang YQ, Guo RD, Guo RM, Sheng W and Yin LR: MicroRNA-182 promotes cell growth, invasion, and chemoresistance by targeting programmed cell death 4 (PDCD4) in human ovarian carcinomas. J Cell Biochem 114: 1464-1473, 2013.

129. Xu X, Ayub B, Liu Z, Serna VA, Qiang W, Liu Y, Hernando E, Zabludoff S, Kurita T, Kong B, et al: Anti-miR182 reduces ovarian cancer burden, invasion, and metastasis: An in vivo study in orthotopic xenografts of nude mice. Mol Cancer Ther 13: 1729-1739, 2014.

130. Liu Z, Liu J, Segura MF, Shao C, Lee P, Gong Y, Hernando E and Wei JJ: MiR-182 overexpression in tumourigenesis of high-grade serous ovarian carcinoma. J Pathol 228: 204-215, 2012

131. Nakayama I, Shibazaki M, Yashima-Abo A, Miura F, Sugiyama T, Masuda T and Maesawa C: Loss of HOXD10 expression induced by upregulation of miR-10b accelerates the migration and invasion activities of ovarian cancer cells. Int $\mathbf{J}$ Oncol 43: 63-71, 2013.

132. Fan X, Liu Y, Jiang J, Ma Z, Wu H, Liu T, Liu M, Li X and Tang $\mathrm{H}$ : miR-20a promotes proliferation and invasion by targeting APP in human ovarian cancer cells. Acta Biochim Biophys Sin (Shanghai) 42: 318-324, 2010.

133. Zou D, Wang D, Li R, Tang Y, Yuan L, Long X and Zhou Q: MiR-197 induces Taxol resistance in human ovarian cancer cells by regulating NLK. Tumour Biol 36: 6725-6732, 2015.

134. Taylor MA and Schiemann WP: Therapeutic opportunities for targeting microRNAs in cancer. Mol Cell Ther 2: 1-13, 2014.

135. Krützfeldt J, Rajewsky N, Braich R, Rajeev KG, Tuschl T, Manoharan M and Stoffel M: Silencing of microRNAs in vivo with 'antagomirs'. Nature 438: 685-689, 2005.

136. Elmén J, Lindow M, Silahtaroglu A, Bak M, Christensen M, Lind-Thomsen A, Hedtjärn M, Hansen JB, Hansen HF, Straarup EM, et al: Antagonism of microRNA-122 in mice by systemically administered LNA-antimiR leads to up-regulation of a large set of predicted target mRNAs in the liver. Nucleic Acids Res 36: 1153-1162, 2008.

137. Hutvágner $G$ and Zamore PD: A microRNA in a multiple-turnover RNAi enzyme complex. Science 297: 2056-2060, 2002.

138. Kota J, Chivukula RR, O'Donnell KA, Wentzel EA, Montgomery CL, Hwang HW, Chang TC, Vivekanandan P, Torbenson M, Clark KR, et al: Therapeutic microRNA delivery suppresses tumorigenesis in a murine liver cancer model. Cell 137: 1005-1017, 2009.

139. Garzon R, Marcucci G and Croce CM: Targeting microRNAs in cancer: Rationale, strategies and challenges. Nat Rev Drug Discov 9: 775-789, 2010.

140. Lu Y, Xiao J, Lin H, Bai Y, Luo X, Wang Z and Yang B: A single anti-microRNA antisense oligodeoxyribonucleotide (AMO) targeting multiple microRNAs offers an improved approach for microRNA interference. Nucleic Acids Res 37: e24, 2009.

141. Dai F, Zhang Y, Zhu X, Shan N and Chen Y: Anticancer role of MUC1 aptamer-miR-29b chimera in epithelial ovarian carcinoma cells through regulation of PTEN methylation. Target Oncol 7: 217-225, 2012.

142. Cittelly DM, Dimitrova I, Howe EN, Cochrane DR, Jean A, Spoelstra NS, Post MD, Lu X, Broaddus RR, Spillman MA, et al: Restoration of miR-200c to ovarian cancer reduces tumor burden and increases sensitivity to paclitaxel. Mol Cancer Ther 11: 2556-2565, 2012.

143. Gambari R, Brognara E, Spandidos DA and Fabbri E: Targeting oncomiRNAs and mimicking tumor suppressor miRNAs: New trends in the development of miRNA therapeutic strategies in oncology (Review). Int J Oncol 49: 5-32, 2016. 